\title{
A Trojan Horse? Sappho's poetry as the battleground of compulsory heterosexuality and lesbian emancipation
}

\begin{abstract}
The ancient Greek poetess Sappho is widely regarded as the oldest known lesbian and feminist in the Western literary history. However, this common notion represents just one in a millennia-long series of reinventions of her persona, since before the fin de siècle her heterosexuality was viewed as an almost indisputable truth. This paper argues that, throughout history, the reception of Sappho's poetry was inevitably faced with the question of her sexuality, which was addressed in very divergent ways. It first uses the theoretical concepts of "Trojan horse" and "compulsory heterosexuality" outlined by feminist critics Monique Wittig and Adrienne Rich to demonstrate that (homo)erotic sentimentality of Sappho's magnificent poems produced a moral complex in Western heteropatriarchal societies, which sought to tame and reclaim that poetry by heterosexualizing it. The paper then turns to a diachronic analysis of various discursive strategies of heterosexualization within the Western literary and philological discourses from antiquity to modernity and contrasts them with the contemporary discourse of homosexualization, thus showing that the reception of Sappho's poetry can be conceptualized as an ideological battle between traditional epistemological regime of compulsory heterosexuality on one hand and modern political aspiration for women's and lesbian emancipation, on the other hand. Finally, the article will illustrate how contemporary philological and historical research on Sappho, in an attempt to escape that ideological battle, unconsciously falls victim to this millennia-long misogyny.
\end{abstract}

\section{Introduction}

No other poet of the classical antiquity would be more astounded with the realization of how great a number of adaptations have been inspired by their poetry and how many fantastical, contradictory and sensational stories have been attached to their life than the archaic Greek poetess Sappho of Lesbos, who lived and wrote during the $7^{\text {th }}$ and $6^{\text {th }}$ centuries BC. From antiquity to modern times Sappho's poetry, written sometimes in joyous, sometimes in disconcerted tone, presented a source of creative inspiration, as well as of raging controversy, because it raised the question of its author's sexuality. Specifically, Sappho's love poetry is characterized by a 
conspicuous expression of female homoerotic sentimentality, which prompted many feminist thinkers, writers and historians to recognize in it a unique female voice in the context of male monopoly over the cultural media in the antiquity: a voice addressing women themselves. This seemed an argument sufficient enough for Sappho to be declared the first feminist and lesbian in the Western literary history, which sparked tremendous cultural consequences and led to the contemporary association of the terms "Sapphic" and "lesbian" with the idea of female homosexuality and related phenomena or practices. In this paper I will argue that this set of cultural events and processes represents just one, although climactic, reinvention of Sappho's life and poetry in a long and complex story of their reception, which had hitherto been marked by multitude of receptive approaches, the majority of which were based on various discursive strategies of heterosexualization.

In other words, I will demonstrate that the reception of Sappho assumed the character of a moral confrontation with the question of her sexuality throughout most of history. In order to illuminate the epistemological roots of this moral complex, I will use the concept of the "Trojan horse", devised by the feminist critic Monique Wittig, to explain the ambivalent character of Sappho's poetry, which simultaneously celebrates and subverts the tradition of Greek lyric poetry and possesses a potential to become socio-politically engaged piece of art. I will then conduct a diachronic analysis of divergent approaches to the reception of Sappho in the Western literature and philology from the antiquity to the present times with an aim of showing that the transhistorical relationship of the Western literary culture towards Sappho can be conceptualized as an ideological battle between the traditional epistemological regime of compulsory heterosexuality and the contemporary movement for lesbian emancipation. Finally, I will evaluate to what extent contemporary philological and historiographic discourses on Sappho, in an attempt to flee from that ideological battle, unconsciously fall victim to the millennia-long misogyny in their approach to the archaic poetess and her work.

\section{Vita Sapphus Lesbiae. Biographical data.}

The possibility of discussion about the circumstances of Sappho's life and poetic activity, as well as her sexuality, is severely hampered by the fact that the extant biographical information on her is so scarce and unreliable that in their book Lesbian Peoples: Material for a Dictionary Monique Wittig and her partner Sande Zeig dedicated a whole page to the famous poetess. The page is blank. ${ }^{1} \mathrm{~A}$ few facts can be deduced by triangulating three types of sources: Sappho's own poems, testimonies and fragments in the works of later ancient authors and the information about the historical context in which the Lesbian lived and wrote. However,

WITTIG \& ZEIG 1979: 136. 
the use of these sources is problematic for several reasons. First of all, numerous philologists and historians have properly pointed out that the autobiographical reading of Sappho's works is misleading and not appropriate. Secondly, ancient authors usually drew data on Sappho's life based on precisely such interpretation of her poetry, deducing unknown from better known facts, which often led them to arrive at completely wrong conclusions. ${ }^{2}$ Thirdly, these authors frequently cite Sappho's poems together with the poems of her famous contemporary Alcaeus, thus making their authorship difficult to discern. ${ }^{3}$

The little we know about Sappho is that she was most probably born in Mytilene on Lesbos, but the $10^{\text {th }}$-century Byzantine encyclopaedia Suda offers Eresus as the alternative. ${ }^{4}$ The date of birth is also unclear, but according to some references in Sappho's poems, it can be estimated at approximately 630 BC. ${ }^{5}$ The name of Sappho's father is likewise unknown and Suda suggests 8 possible variants. The same work states that the poetess had a mother named Kleïs and that her husband was a wealthy merchant from the island of Andros, called Kerkylas, with whom she had a daughter, also called Kleïs. ${ }^{6}$ However, philological analyses disputed

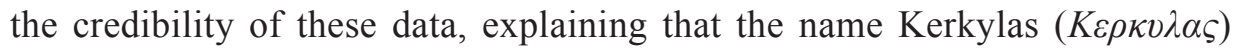
resembles the ancient Greek word for penis (ке́ркоऽ) and is unattested in the currently known corpus of ancient Greek homonyms, whereas the name of the island $(A v \delta \rho o \sigma)$ looks similar to the Greek word for man $(\dot{\alpha} v \eta \dot{\eta} \rho)$. Therefore, the construction "Kerkylas from Andros" can be considered a witty pun translatable as "Dick Cocklord from the Island of Man", which was most probably recycled from the classical Athenian comedy and its representation of Sappho as a licentious hetaira. ${ }^{7}$ The names of Sappho's mother and daughter offered by Suda should also be taken with a degree of scepticism. For although Kleïs appears as the daughter of the speaker in two of Sappho's poems, it is well-known that ancient Greeks tended to name their children after their parents, which makes it highly possible that later authors simply deduced the name of Sappho's mother from the supposed name of her daughter. ${ }^{8}$ Furthermore, Suda states that Sappho had three brothers, Erygius, Larichus and Charaxus, of whom the latter two are mentioned in the recently discovered Brother's Poem. ${ }^{9}$ According to Athenaeus, Larichus was praised by his sister as the wine pourer in the hall of Mytilene, ${ }^{10}$

RAYOR \& LARDINOIS 2014: 1-2.

RAYOR \& LARDINOIS 2014: 5.

$4 \quad$ Suda $\Sigma, 107$ = VANDIVER 1998.

5 CAMPBELL 1982: 10-11.

$6 \quad$ Suda $\Sigma, 107$ = VANDIVER 1998.

7 PARKER 1993: 309.

8 RAYOR \& LARDINOIS 2014: 3-4.

$9 \quad$ Suda $\Sigma, 107$ = VANDIVER 1998. 
a service usually reserved for sons of prominent families, ${ }^{11}$ while several other sources mention that Charaxus was reprimanded as a profligate by Sappho for having wasted a huge fortune on his lover, an Egyptian courtesan named Rhodopis, who some authors call Doricha. ${ }^{12}$ However, having in mind the illusiveness of autobiographical reading of Sappho's poetry, Larichus and Charaxus may have been a mere product of the lyricist's creative imagination. ${ }^{13}$ No matter how difficult to confirm the information about Sappho's life may be, it is certain that she belonged to a wealthy aristocratic family and lived at the time when Lesbos was shaken by political rivalries and conflicts between such families, which is also confirmed in the poems of her contemporary Alcaeus. Possibly, Sappho's family chose the wrong side in these conflicts, since the Parian Chronicle states that between $604 / 3$ and 596/5 BC the poetess went into exile to Sicily, ${ }^{14}$ where she might have lived until the middle of the $6^{\text {th }}$ century BC.

\section{Carmina et fragmenta tradita. Manuscript tradition.}

Our current knowledge and understanding of Sappho's life and work is made more difficult by the narrow scope and precarious condition of her extant works, which led the American classicist and columnist Daniel Mendelsohn to claim that "it would be hard to think of another poet whose status is so disproportionate to the size of her surviving body of work." ${ }^{15}$ Apart from that, it is unknown how much of that work was written by Sappho herself or whether it contains some emendations and supplements by later authors. Specifically, it is to be borne in mind that the ancient Greek lyric poetry was transferred from one generation to the other by word of mouth until some sympathiser recognized a particular poem

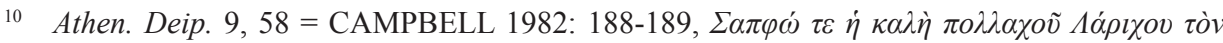

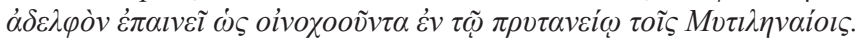

11 CAMPBELL 1982: 189.

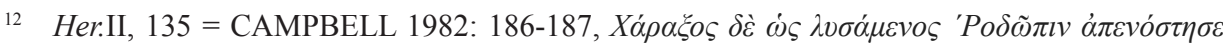

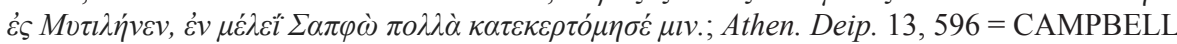

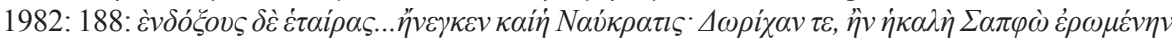

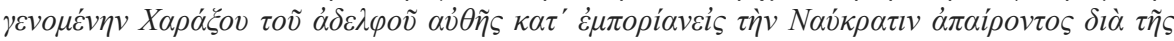

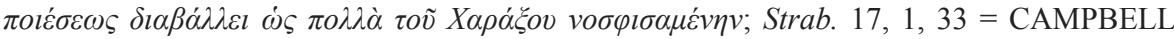

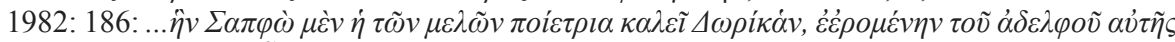

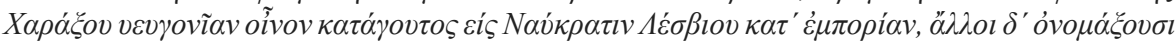

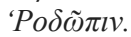

13 RAYOR\&LARDINOIS 2014: 3.

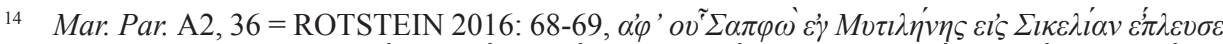

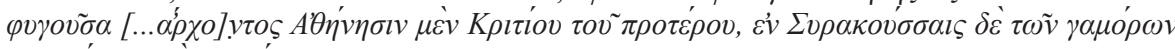

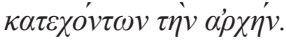

OBBINK 2016: 42. 
as exquisite and decided to write it down to save it from eternal oblivion. It is known that Hellenistic scholars of the Alexandrian library classified Sappho's entire work available at the time into a compendium of at least eight books, which comprised around 10000 verses. ${ }^{16}$ There were probably other Alexandrian editions of Sappho's poetry, as well as other ancient anthologies, apart from the Alexandrian ones. Anyhow, the scope of Sappho's work circulating in Antiquity was so great that the $3^{\text {rd }}$-century BC Greek poet Posidippus of Pella self-assuredly claimed that it would live "as long as ships sail the Nile." ${ }^{17}$ However, by the $9^{\text {th }}$ century the majority of the ancient corpus went completely lost and the $12^{\text {th }}$-century Byzantine poet and grammarian Isaac Tzetzes lamented that the time had destroyed Sappho and her poetry. ${ }^{18}$ Factors such as humidity, fire, negligence and misogynistic Church Fathers had reduced Sappho's extant opus to a minimum. ${ }^{19}$ Nonetheless, archaeological excavations that started towards the end of the $19^{\text {th }}$ century at Oxyrynchus in Egypt resulted in the discovery of a rich collection of ancient papyri, some of which contained fragments of Sappho's poems. Yet, of some 10000 verses which formed the Alexandrian edition, only about 650 remain. They include only one fully extant poem, the so-called Ode to Aphrodite, ${ }^{20}$ a dozen of somewhat longer fragments containing half of the original lines, about a hundred of short citations by later ancient authors and around fifty scraps of papyrus with a single line or word. ${ }^{21}$

\section{Decima musa aut equus Troianus? The character of Sappho's poetry.}

In spite of such poor scope of information about Sappho's life and work, it is necessary to offer an insight into the character of her extant opus, since it was precisely its peculiarity and ambivalence that planted the seed of the moral complex that for millennia dominated the attitude of the Western literary culture towards the renowned Lesbian. With that in mind, Sappho should above all be observed as an exceptional representative of the tradition of archaic lyric poetry, written in the Aeolic dialect of the Ancient Greek and performed to the accompaniment of a lyre. ${ }^{22}$ Her poems were intended for both monodic and choral execution. Thematically, the majority of her preserved opus consists of love and erotic

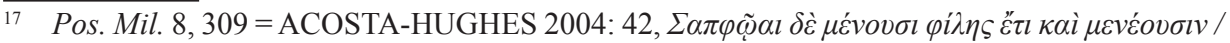

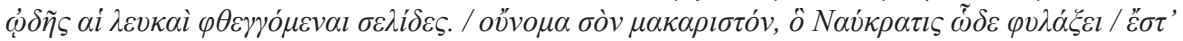

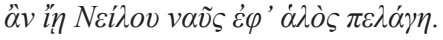

18 Test. $16=T z . \pi . \Pi$.

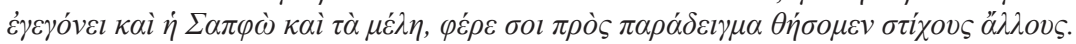

19 WILLIAMS 1995: 41-42.

20 Sappho, fr. 1 = CAMPBELL 1982: 52-55.

21 RAYOR \& LARDINOIS 2014: 7.

22 CAMPBELL 1982: 10.
} 
poetry dedicated to other women, but she also wrote religious hymns, wedding, symposiac and satirical poems, while one fragment even displays characteristics of the Homeric epic. ${ }^{23}$ Despite their typological differences, all these poems are distinguished by their sublime writing style, picturesque integration and reinvention of mythological motives, innovation in metrics, which Sappho enriched with the so-called "Sapphic stanza", consisting of three long and one short verse, as well as by skilful alternations between short, long and free syllables.

This creative originality and technical wizardry ensured Sappho a unique status among the archaic poets already in the antiquity, so that Plato allegedly called her the tenth Muse ${ }^{24}$ and Aelian related a story about the Athenian statesmen Solon, who, upon hearing his nephew sing one of her songs, was so astonished that he desired to be taught its every verse so "that I may learn it and then die." ${ }^{25}$ But what makes her poetry stand out from all other archaic poets is her distinct female character, an odd feature in the literary tradition that was initiated and dominated by men such as Archilochus, Hipponax, Semonides, Alcaeus, Anacreon and others. Their poems were inspired by the dynamic of everyday events within the circle of male friends, who entertained each other with dedicatory hymns, eulogies, moral remarks, reminiscences of shared ups and downs, departures and reunions, aging and death, as well as of mutual homoerotic escapades. ${ }^{26}$ Sappho's poetry adheres to these conventional features of archaic Greek poetry, but it simultaneously subverts that tradition by introducing women as speakers and addressees, as well as by accentuating the typically feminine character of its themes, motives and diction. Furthermore, many of her poems celebrate physical attractiveness and loveliness of young women through a subtle expression of homoerotic affectivity. For instance, the famous Fragment 1 invokes Aphrodite to console the lyric subject in her suffering caused by the unrequited love for a young woman. ${ }^{27}$ Fragment 16 expresses painful yearning for the young Anactoria, who acquiesced to the norms of heteropatriarchal society and entered marriage. ${ }^{28}$ Similarly, Fragment

$23 \quad$ RAYOR \& LARDINOIS 2014: 7-9.

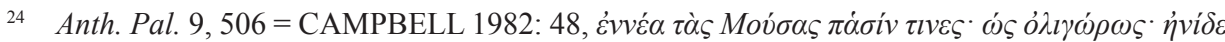

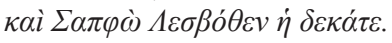

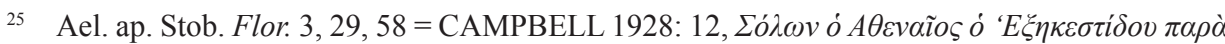

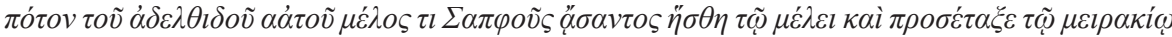

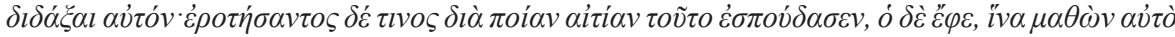
$\dot{\alpha} \pi \circ \theta \dot{\alpha} v \omega$.

PARKER 1993: 340.

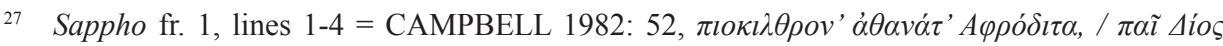

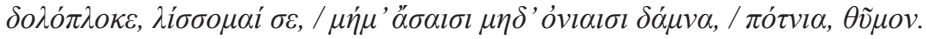

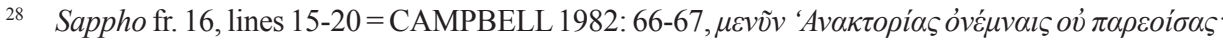

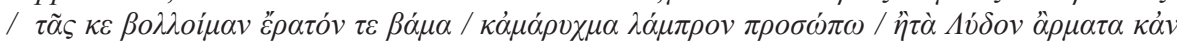

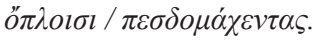


49 communicates a longing for the gone girl Atthis, ${ }^{29}$ while the female speaker in Fragment 94 accompanies her friend on departure, recalling the sensual delicacies they once exchanged. ${ }^{30}$ Particularly melancholic tone is assumed in Fragment 96, which describes the physical manifestations of the unrequited love towards another woman. ${ }^{31}$

All these examples demonstrate how Sappho interweaves the subversive feminine and homoerotic nature of her poetry into the fabric of the dominant literary discourse of her time, thus becoming a kind of an interloper, which Monique Wittig metaphorically calls the "Trojan horse". The concept refers to a textual entity whose recognizable form renders it familiar and magnificent within the literary tradition in which it comes to existence, but whose simultaneously strange, subversive and rebellious inner characteristics stimulate a certain degree of suspicion, discomfort and anxiety in a conservative society, which accordingly resorts to various ways of taming and reclaiming it. However, when political, social and cultural circumstances change and pave the way for recognizing, comprehending and accepting this ambivalent character of the "Trojan horse", it becomes a socio-politically charged piece of art, while its subversive elements come to be perceived as the its very essence, as well as the symbol of its author. ${ }^{32}$ In the same manner, Sappho's poetry possessed uniqueness of metric, vividness of motives and eminence of style, which gave it an appearance of a masterpiece of the archaic Greek lyric poetry, yet its hitherto unseen mention of homoerotically connoted female affectivity appeared extravagant and abominable, because it challenged the fundamental epistemological regime that historically defined the European culture, a regime that queer-theorist Adrienne Rich describes as "compulsory heterosexuality". It refers to a transhistorical and transcultural set of assumptions about the normativity of heterosexuality as the very foundation of social existence, organization and evolution. Thus every deviation from this norm is perceived as undesirable, perverted and dangerous and is thus subjected to societal and cultural sanctions which seek to suppress, exterminate or assimilate it. ${ }^{33}$ In accordance with this, from Antiquity to the late $19^{\text {th }}$ century, Sappho's poetry provoked a variety of receptive reactions that were often directed at justifying, rationalizing and expiating its ambivalent character, all of which resorted to different discursive strategies of heterosexualization.

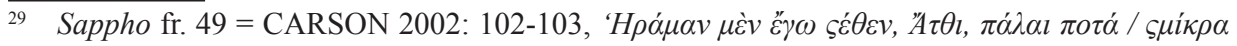

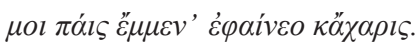

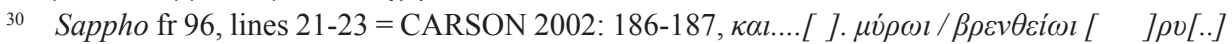

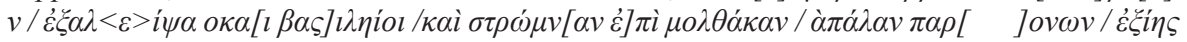
$\pi \dot{\theta} \theta o[v \quad] v i ́ \delta \omega v$.

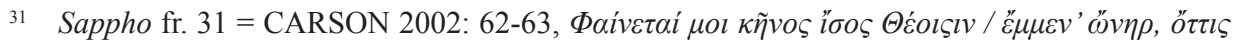

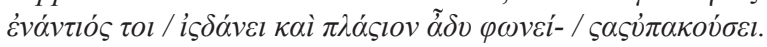

32 WITTIG 2010: 60-62.

33 RICH 1990: 638-640. 
Fornicatrix aut herois tragica? Sappho in Antiquity and the early Middle Ages.

The beginning of Sappho's heterosexualization in the Western literary culture can be traced back to the classical period of Ancient Greece, when some Athenian writers, shocked by the erotic language used by a woman, started discussing Sappho's sexuality, perceiving her at first as a licentious harlot. ${ }^{34}$ This tradition started with the classical Athenian comedy from $5^{\text {th }}$ to $3^{\text {rd }}$ century $\mathrm{BC}$, which represented Sappho as a courtesan resembling Athenian hetairai, a class of welleducated elite prostitutes. There are six known Attic comic poets of the early, middle and late period who wrote works dedicated to Sappho. ${ }^{35}$ For instance, while Antiphanes presented the poetess as composer of riddles in the context of a Greek symposium, associating her thus with witty hetairai, ${ }^{36}$ Dyphilus anachronistically ascribed to her Archilochus and Hipponaxas as lovers, ${ }^{37}$ whereas one hetaira in a comedy by Epicrates boasts about her extensive knowledge of Sappho's poetry. ${ }^{38}$ This tradition continued through the Hellenistic period, when elegist Hermesianax in the $4^{\text {th }} / 3^{\text {rd }}$ century BC mentioned Sappho's supposed affairs with Alcaeus and Anacreon ${ }^{39}$ and epigrammatist Philodemus in the $1^{\text {st }}$ century BC insinuated that hetairai sang Sappho's poems during coitus. ${ }^{40}$ Representation of Sappho as a courtesan was probably related to the spread of stereotypes about unrestrained sexual predilections of Lesbian women. This is indicated by the verb lezbiazein $(\lambda \varepsilon \zeta \beta l \alpha \zeta \varepsilon l v)$, which in the classical period came to denote the sexual practice of fellatio, thus associating Lesbian women with unconventional forms of sexual behaviour. ${ }^{41}$ Remnants of this stereotype, as well as of the related tradition that treated Sappho as a disreputable fille de joie, can be traced to the Roman period, when Catullus in the $1^{\text {st }}$ century $\mathrm{BC}$, and Horatius in the $1^{\text {st }}$ century $\mathrm{AD}$, wrote a series of works, describing promiscuous, although never homosexual, adventures

34 PENROSE 2014: 420.

35 PARKER 1993: 309-310.

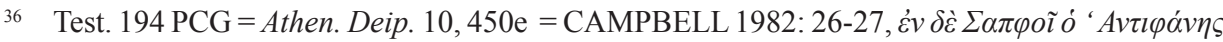

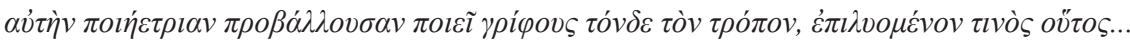

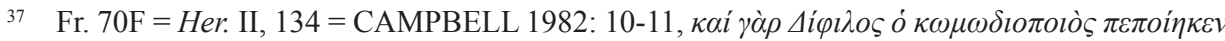

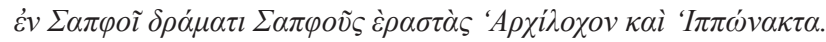

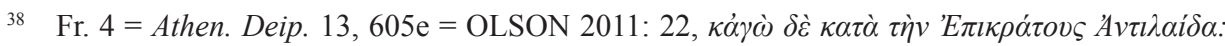

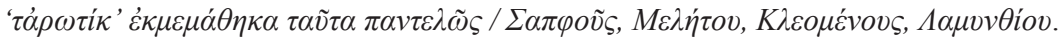

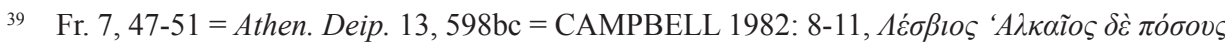

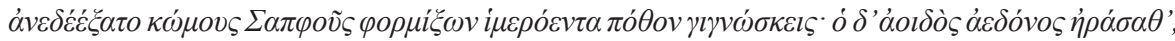

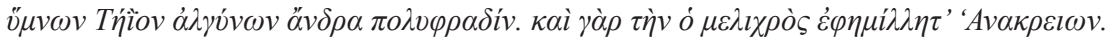

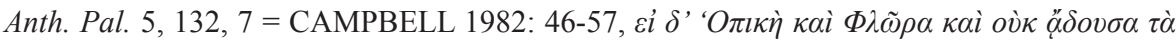
$\Sigma \alpha \pi \varphi \omega \tilde{v} \varsigma .$. 
of a girl named Lesbia. ${ }^{42}$ In similar fashion, Propertius introduces Sapphic motives when he delineates seductive qualities of a promiscuous woman..$^{43}$ The connection of Sappho with the idea of female eroticism can further be found in the works of Ovid ${ }^{44}$ and Apuleius. ${ }^{45}$ These ignominious narratives and tropes were difficult to reconcile with the continuous increase of admiration towards Sappho's poetic eminence, producing a difficult moral complex, whose solution was sought in the discursive strategy of duplication. As indicated by its name, this strategy was based on splitting up of Sappho's person on two morally antithetical characters, one of whom was the glorious poet who cultivated normative relations with her family and female acquaintances mentioned in the poems, while the other figured as a grotesque and libidinous courtesan..$^{46}$ The earliest trace of this discursive strategy can be located in the works of the $3^{\text {rd }}$-century BC author Nymphodorus, ${ }^{47}$ followed by Seneca the Younger in the $1^{\text {st }}$ century $\mathrm{BC} / 1^{\text {st }}$ century AD, who derides some useless philological ventures of his time and in this connection mentions a treatise by Dydimus, that implies the existence of two Sapphos, a poet and a prostitute. ${ }^{48}$ The strategy is again deployed by $3^{\text {rd }}$-century rhetorician Athenaeus, who writes of two Sappho's, a celebrated poet, on the one hand, and the less-known courtesan, on the other hand. ${ }^{49}$

In parallel with narratives about Sappho as a courtesan and the discursive strategy of duplication, a series of $3^{\text {rd }}$-century BC anonymous Hellenistic commentators, appalled at homoerotic implications of Sappho's poetry, started to tackle the question of the lyricist's homosexuality. ${ }^{50}$ These debates continued into the Roman times, when 1st-century BC lyric poet Horace stated that the Sappho

42 Cat. Carm. 51 = COMISH 1913: 58-61, Ille mi par esse deo videtur...qui sedens adversus identidem te spectat et audit; Cat. Carm. 58 = COMISH 1913: 66-67, ...illa Lesbia...nunc in quadriviis et anguiportis / glubit magnanimi Remi nepotes; Hor. Epod. 12, 17 = RUDD 2004: 300-301, pereat male, quae te Lesbia quae rentit aurum monstravit inertem...

43 Prop. Eleg. II, 3, 17 - 22 = KATZ 2004: 88-89, lili non domina sunt magis alba mea / ...nec de more comae per levia colla fluentes / ...et quantum, Aeolio cum temptat carmina plectro ,/ par Aganippaeae docta lyrae; / et sua cum antiquae comittit scripta Corinnae, / carminaque illius non putat aequa suis. Apul. Apol. 9 = JONES 2017: 35-36,...etiam mulier Lesbia, lascive illa quidem tantaque gratia, ut nobis in solentiam linguae suae dulcedine carminum commendet... MOST 1995: 17-18.

47 MOST 1995: 18.

Sen. Epist. 88, 37 = CAMPBELL 1982: 22-23, quattuor milia librorum Dydimus grammaticus scripsit: misererer si tam multa supervacua legisset...in his libris quaererit...an Sappho publica fuerit...

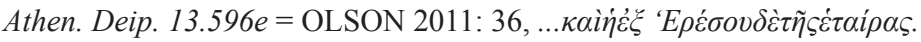


sexually interacted with her female friends and referred to her as mascula. ${ }^{51} \mathrm{~A} 2^{\text {nd }}$ century commentator of his works Pomponius Porphyrion explained that Sappho was considered masculine because she pursued a typical male activity of writing poetry, but also because she was a tribade. ${ }^{52}$ In the same century, satirist Lucian in his Dialogues of Courtesans alluded to the presence of homosexual behaviour on Lesbos and related a dialogue in which courtesan Leaena brags about having had an affair with a virile Lesbian called Megilla, whereupon her friend informs her of rumours about Lesbos being populated by dykes who copulate exclusively with other women. ${ }^{53}$ Likewise, a $2^{\text {nd }}$-century papyrus from Oxyrynchus reprimands Sappho for leading a lecherous life marked by homoerotic escapades. ${ }^{54}$

Since Sappho's poetic talent and glory could be ignored about as hardly as the stigma caused by her alleged erotic interest in other women, another moral complex developed, which gave birth to the discursive strategy of narrativization. It consisted of integrating disparate elements of various literary traditions about Sappho and arranging them along the single temporal axis of her biography, so that those deemed disgraceful lost their significance by virtue of being chronologically situated before the onset of the poetess' cognitive, social and moral maturation. In other words, homosexuality became only one part of Sappho's fictional biography, where it figured as a shameful moral stigma of her licentious youth, which was expiated in the moment when she surrendered herself to the normative heterosexual form of love. ${ }^{55}$ The earliest testimony of this strategy comes from the Athenian comic poet Menander in the $4^{\text {th }} / 3^{\text {rd }}$ century BC, who related the story about Sappho undertaking a suicidal leap from the white cliff of Leucas into the Ionian Sea because of the unrequited love for a ferryman named Phaon. ${ }^{56}$ Although Phaon is not mentioned in any of Sappho's extant poems and the related tale was in all likelihood a fiction inspired by the mythological episode in which desperate Aphrodite jumps from the same place to free herself from pain caused by unreciprocated love for a certain Phaon, ${ }^{57}$ Menander's narrative was retold again by Ovid in the $1^{\text {st }}$ century AD, who

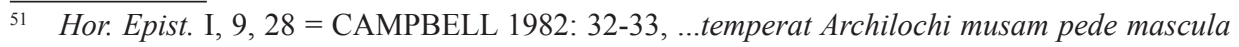
Sappho.

52 Porphyr. Test. 17 = CAMPBELL 1982: 18-19, 'mascula' autem 'Saffo', vel quia in poetico studio est, in quo saepius viri, vel quia tribas diffamatur fuisse.

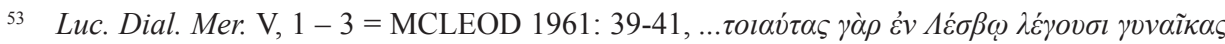

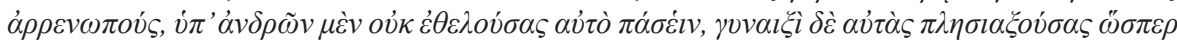
$\ddot{\alpha} v \delta \rho \alpha \varsigma$.

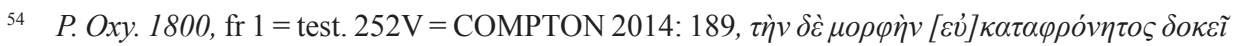

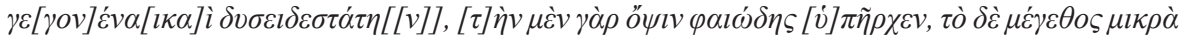
$\pi \alpha \nu \tau \varepsilon \lambda \tilde{\omega} \varsigma$. MOST 1995: 19.

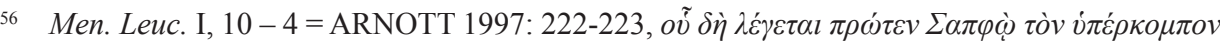

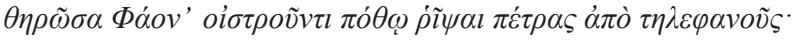


in his $15^{\text {th }}$ Heroide brought forth a supposed letter from Sappho to Phaon. In it, the poetess in an embarrassed tone confesses that homosexual relationships are a matter of her past and emphasizes that her only current concerns are the profligacy of her brother, the burdensome task of raising her daughter and the unreciprocated love for Phaon, which ultimately prompts her to commit suicide by precipitating herself from the promontory of Leucas. ${ }^{58}$ Ovid's story was cited by Pliny the Elder in the $1^{\text {st }}$ century ${ }^{59}$ and later, in a somewhat modified form, by Athenaeus in the $3^{\text {rd }}$ century, who wrote of a promiscuous namesake of the great poetess who was unhappily enamoured with the beautiful Phaon. ${ }^{60}$

Early Christian sources, preoccupied with the issue of legitimizing the new soteriological monotheism as an alternative to the "abominable" polytheisms and the remaining heritage of the pagan Antiquity, resorted to fervid demonization of Sappho from the Judeo-Christian moral standpoint, which regarded promiscuity and homosexuality as unmentionable vices. Ignoring the quality of Sappho's poetry, they turned to the old discursive strategies of duplication and narrativization. For example, the $2^{\text {nd }}$-century Church Father Tatian denounced the ancient poetess as a whore who sang of her own wantonness. ${ }^{61}$ Moreover, according to the story written by the $16^{\text {th }}$-century Italian polymath Hieronymus Cardanus, the $4^{\text {th }}$-century Archbishop of Constantinople Gregory of Nazianzus ordered Sappho's works to be burned because of their reprobate content, and a contemporary of Cardanus, the French historian Joseph Justus Scaliger wrote that Sappho's poetry was accused of immorality and burned in 1073 at Rome and Constantinople on the order of Pope Gregory VII. ${ }^{62}$ Although both stories may only be Renaissance legends, they clearly illustrate the attitude of the early Christianity towards Sappho. Particularly interesting is the case of the already mentioned Byzantine encyclopedia Suda, which represents a unique attempt to reconcile the strategies of duplication and narrativization. It first mentions two Sapphos, an outstanding poetess from Eresus $^{63}$ and a less-talented harpist of lower social standing from Mytilene, ${ }^{64}$ the latter

58 Ovid. Her. 15 = SHOWERMAN 1914: 181-197, lines 16-19, vilis Anactoriae, vilis mihi candida Cydro; / non oculis grata est Atthis, ut ante, meis, / atque aliae centum, quas hic sine crimine amavi; 63-66, arsit inersfratermeretricis captus amore / ...quasque male amisit, nunc male quaerit opes; 70, accumulat curas filia parva meas; 219-220, hoc saltem miserae crudelis epistula dicat, / ut mihi Leucadiae fata petantur aquae!

59 Plin. NH. 20, 22 = JONES 1951: ...ob hoc et Phaonem Lesbium dilectum a Sappho.

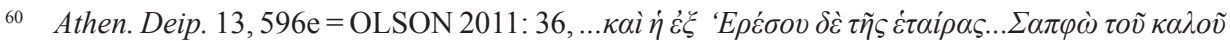

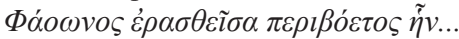

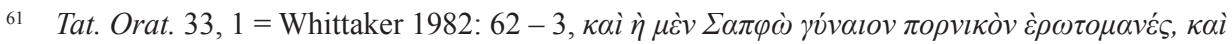

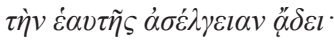

62 PENROSE 2014: 421-423.

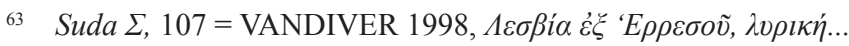

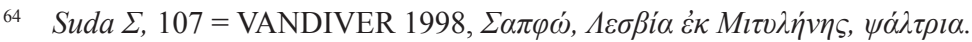


of which evokes the ancient tradition which treated Sappho as a courtesan. The Suda goes on to state that the poetess from Eresus faced charges for homosexual intercourse with her friends, but adds that she eventually married Kerkylas from Andros and bore him a daughter. ${ }^{65}$ By contrast, Sappho the harpist is connected to the story about Phaon and the suicidal leap. ${ }^{66}$ Therefore, Suda partly draws on the strategy of duplication insofar as it constructs two different personas, distinguished by their sexuality, place of birth, occupation and reputation, but both characters betray the intention of the authors to challenge the traditions which they felt did harm to the moral standing of the glorious lyricist. Thus they expiate Sappho the poetess by placing her into the context of marriage and motherhood and use the story of Sappho the harp-player to euphemize the tradition connecting the poetess with prostitution. ${ }^{67}$

\section{Fornicatrix cunum lingendo redempta. The Renaissance Sappho.}

Renaissance humanism was occupied with finding a way to reconcile the enthusiasm for imitating and emulating pagan antiquity with the demands of the late medieval Christian morale, which ostracized prostitution and homosexuality as ineffable sins. In that context, the main concern was the punishment of male homosexuality, while its female counterpart received some attention, ${ }^{68}$ but the general cultural trend was marked by its neglect or censorship. In the reception of Sappho this resulted in a complex endeavour to present the Lesbian as an example of a first-class versifier and to either erase every homoerotic element from her biography or completely desexualize her persona. ${ }^{69}$ The main source of information on the ancient poetess became Ovid and the 15-th century antiquarians recognized his verbose, intriguing and flamboyant story as an authentic testimony of Sappho's life, thus transforming it into the most relevant and widely used authority in the history of Sappho's reception. ${ }^{70}$ Representative examples of this approach in the Renaissance literature are the treatise On Famous Women by Giovanni Boccaccio from 1374, the proto-feminist writings The Book of the City of Ladies by Christine de Pizan from 1405 and In Praise of Women by Bartolommeo Goggio from 1487.

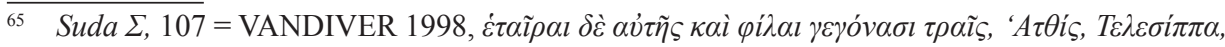

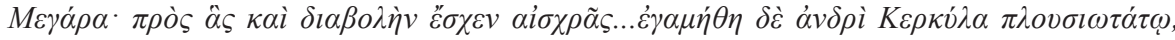

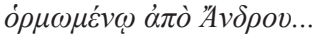

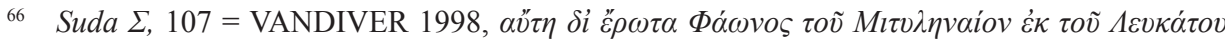

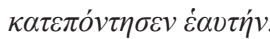

MOST 1995: 18-19.

68

PUFF 2011: 145-155.

PENROSE 2014: 417.

MOST 995: 419. 
Boccaccio's work was the first studious collection of female biographies in the Western literary history, which inspired the already mentioned writing of Christine de Pizan, as well as later biographical collections featuring illustrious women. Written in moralizing tone and from typical medieval standpoint, intoxicated by prejudice against women as intellectually challenged, sexually provocative and morally inferior beings, Boccaccio's work provided representative examples of desirable and undesirable behaviour of prominent female historical figures, which ought to have served as moral guidance for future generations of educated Italian daughters. Sappho herself is portrayed as an exceptional writer and player of lyric poetry, residing among the Muses on Parnassus. However, Boccaccio contrasted Sappho's poetic glory with her unfortunate romantic life, recycling Ovid's narrative about her Leucadian leap and blaming the Muses for failing to invoke in Phaon the passion towards the graciousness of her verses. ${ }^{71}$ Since he used Heroides as the source for Sappho's biography, Boccaccio must have been acquainted with the part of Ovid's story telling of the poetess' homosexual past, but obviously decided to omit it from his work. ${ }^{72}$

Although inspired by Boccaccio's biographic style, French court poetess Christine de Pizan rejected his misogynistic perspective and composed The Book of the City of Ladies as an apology of womankind and a reaction to The Romance of the Rose by Jean de Meung, who had denigrated French noblewomen as rapacious seductresses. In order to reveal the groundlessness of such accusations, she collected stories of illustrious women, using them as metaphorical stone blocks to build an allegorical city of ladies, thus fixing on parchment the long tradition of laudable female participation in the creation and development of Western culture. Discussing the problems faced by women of all classes through exclusively female opinions, experiences and issues, de Pizan emphasized the need for greater visibility and better education of women as the best strategy for overcoming the universal misogyny that plagued the $14^{\text {th }}$-century French elite. ${ }^{73}$ Her Sappho thereby figures as an eminent example of a female poet and erudite, but her sexuality and promiscuity are erased from the story. This is so because de Pizan wished to free the womankind of male moral rebukes, which prompted her to depict Sappho as a moral puritan and example for all future poetesses, that is, to censure both the tradition treating the famous Lesbian as a courtesan and Ovid's narrative because of its disreputable homoerotic moment, albeit she must have been familiar with it through Boccaccio. Moreover, she remained faithful to

\footnotetext{
71 Bocaccio, De Claris Mulieribus, 47 = BROWN 2003: 95-96, Are the muses to be blamed? They were able to move the stones of Ogygya when Amphion played, but they were unwilling to soften the young man's heart in spite of Sappho's songs.

72 PENROSE 2014: 27.

73 BREMER 2004: 71.
} 
heteronormative Judeo-Christian moral values when she stated that any man who offends women sins against nature because "there is no bird or beast that does not naturally seek out its other half, that is to say the female." $" 74$

In his treatise Bartolommeo Goggio took a step further than de Pizan in advocating the better position of women in society. Writing under the patronage of extremely influential Eleanor of Aragon, he compiled biographical entries on memorable women in order to communicate the idea of not only gender equality, but of the moral superiority of women, who he went on to call "the first sex". For his series of biographies he used the Suda, copies of which had been brought to Italy by exiled Byzantine intellectuals after the Ottoman capture of Constantinople in 1453, as well as Ovid, who was one of the most popular ancient authors among the Renaissance literati. ${ }^{75}$ Following the model outlined in the Suda, he constructed two Sapphos: a virtuoso poetess from Eresus in the company of six talented pupils, who in their masterful poetry outmatched all male contemporaries, and an equally skilled lyricist from Mytilene, who he credited with the invention of the Sapphic stanza and friendship with the Muses. Inspired by the $15^{\text {th }}$ Heroide, he then proceeded to insert the tale of Phaon and the Leucadian leap into the story about the Mytilenian. ${ }^{76}$ In so doing Goggio's work integrated and reconciled two discursive strategies hitherto used in the assessment of Sappho: he first posited the modified strategy of duplication as the framework of his biographical study and then actualized the Ovidian discursive strategy of narrativization within that framework.

A somewhat different trend can be observed in the late-Renaissance philology, whose sporadic interest for lesbian activities mentioned in Juvenal's satires and Martial's epigrams led to the partial revitalization of discussions about Sappho's homoeroticism in the late $15^{\text {th }}$-century Italy. In fact, both ancient authors wrote of homosexual adventures of women in a sneering tone: while Juvenal mocked lesbian sexual practices like cunnilingus and tribadism, ${ }^{77}$ Martial's epigrams introduced the grotesque, robust and hypersexual character of a tribade called Philaenis, who "devours eleven girls a day." Italian humanist Domizio Calderini brought up Horatius' and Porphyrio's characterization of Sappho as a manlike tribade so as to draw a parallel between the sexual behaviour of Philaenis and that of the ancient poetess, as well as to locate the ori-

74 PIZAN 1992: 34.

75 PENROSE 2014: 429-430.

76 PENROSE 2014: 430-431.

77 Juv. Sat. VI, lines 300-301,...quid enim Venus ebria curat? / inguinis et capitis quae sint discrimina nescit; 314-315, nota Bonae secreta deae, cum tibia lumbos / incitat; 320-322, leonum ancillas posita Saufeia corona / provocat et tollit pendentis praemia coxae, / ipsa Medullinae fluctum crisantis adorat

78 Mar. Epi. VII, 63, 3 =SCHACHTER 2015, pedicat pueros tribas Philaenis / et tentigine saevior mariti / undenas dolat in die puellas. 
gin of tribadism on Lesbos. ${ }^{79}$ Similar statements concerning Sappho can be found in Calderini's 1475 edition of Ovid's Heroides, as well as in the studies of other Italian philologists from the late $15^{\text {th }}$ and early $16^{\text {th }}$ centuries, who were inspired by Calderini. For instance, Antonius Volscus and Ubertinus Clericus in their 1496 commentary on Ovid asserted that Sappho openly professed her tribadism and pursued shameful relationships with other women. ${ }^{80}$ Also, the proliferation of printed press intensified the dissemination of Calerini's edition of Heroides across Italy and Europe, sparking four Venetian editions towards the end of the $15^{\text {th }}$ century, as well as editions principes in France in 1500 and England in $1567 .{ }^{81}$ Following this trend, in 1545 Giglio Gregorio Giraldi published a comprehensive encyclopaedia of doxographies and commentaries on the most notable pieces of ancient Greek and Roman poetry with a biographic entry on Sappho, in which he stated that the poetess was notorious for her promiscuous tribadism prior to falling in love with Phaon. ${ }^{82}$ His statement was repeated by the influential French philologist Henri Estienne in his 1566 edition of ancient Greek lyric poetry. ${ }^{83}$ Overall, it can be observed that the late-Renaissance philology established Ovid as the main source of information on Sappho's life, thus shedding a new light on the issue of Sappho's homoeroticism, which the Renaissance humanist discourse had been trying to cloud for almost two centuries. However, the former policy of silence was replaced by homophobic anathematizing of Sappho's sexuality as a perverted abomination.

\section{Florat Ovidius! Sappho in early modern Europe}

As opposed to the Renaissance strategy of neglecting and concealing, early modern literary and philological discourses followed the steps of Calderini and his successors by broaching the subject of Sappho's sexuality, whereby they wholeheartedly turned to Ovid and the discursive strategy of narrativization by representing Sappho as an unfortunate heterosexual heroine who was trying to wash away the stigma of her homosexual past. The first signs of this trend can be discerned in Northwest Europe, where in 1523 Erasmus of Rotterdam in one of his Colloquies, titled The Virgin Averse to Matrimony, introduced the character of Eubulus, who is trying to divert his beloved Catharina from ordination, stating that many nuns enter their service so that they could secretly practice the shameful behaviour of the ancient poetess Sappho. ${ }^{84}$ Even though the implications of

\footnotetext{
79 SCHACHTER 2015: 5-6.

80 REESER 2015: 268.

81 ANDREADIS 2001: 29-31.

82 SCHLESIER 2013: 844.

83 REESER 2015: 268.

84 Erasmus, Virgo misogamos 108 = BAILEY 1725: 151, Because there are more among 'em that imitate Sappho in Manners, then are like her in Wit.
} 
Eubulus' warning are beyond grasp to the uneducated Catharina, they certainly resonated very clearly among the learned members of Erasmus' cultural milieu, who must have been acquainted with Ovid's story of Sappho's unrestrained youth through the Italian humanist literature. The work of Erasmus thus resounded loudly among the European intellectual elite of the $16^{\text {th }}$ and $17^{\text {th }}$ centuries, which as a consequence further popularized the $15^{\text {th }}$ Heroide as a source on Sappho's life.

Experiments with the strategy of narrativization are especially visible in the French and English literature of the latter half of the $16^{\text {th }}$ century. In France this trend is best exemplified by the poetry of Louise Labé, who drew inspiration from the $15^{\text {th }}$ Heroide in order to write 3 elegies and 24 sonnets about the love of a woman for an unnamed man ${ }^{85}$ as well as by the works of the La Pléiade group of poets, whose members imitated Petrarca and ancient authors, including Sappho. For instance, Estienne Lesart produced an adaptation of Sappho's Fragment 1, removing from it every implication of homoeroticism. ${ }^{86}$ By contrast, his colleagues Pierre de Ronsard, Etienne Jodelle and Pontus de Tyard openly experimented with the homoromantic undertone of Sappho's poetry, combining it with Neoplatonist philosophy of love in several elegies dealing with unhappy female-to-female love. However, despite challenging the dominant homophobic mentality of their time, the lesbian eros of La Pléiade poets was essentially a creative experiment that helped male cultural subjects to speculate with the Neoplatonic philosophy and fantasize about the liberation from the restraining carnality of heterosexual love in order to reposition themselves into a sphere of sublime and incorporeal samesex romanticism. In doing so, they by no means undermined the sustainability of the discursive strategy of narrativization, which delegitimized lesbianism as deleterious and ephemeral. ${ }^{87}$

At the same time, Sappho experienced several reinventions in the English literature of the Elizabethan era, which in its cultural choices also demonstrated a particular interest for emulation of ancient literary models. The first to be mentioned in this context is the court poet, dramatist and Shakespeare's rival John Lyly, who in 1584 published his comedy titled Sappho and Phao. Its plot is set in the prosperous ancient Sicilian town of Syracuse, the residence of the powerful and beautiful queen Sappho, ${ }^{88}$ whose pride the envious goddess Venus decides to punish by turning the old and poor seaman Phaon into an attractive youth and deploying him to Syracuse

85 LABÉ 2014: 65-88, sonnet 17, Ovid's Sappho similarly declares to Phaon: Obsessed as I am, you visit me by night,/Phaon, in dreams more candid than daylight.../But sleep's delightsare too short-lived by far.

SCHLESIER 2013: 845. hard to judge, whethershe be more beautiful or wise, virtuous or fortunate. 
to steal Sappho's heart. ${ }^{89}$ However, Venus herself unexpectedly falls in love with the product of her spell and demands from her son Cupid to hit the youngster with his arrow of love towards her and an arrow of hate towards Sappho. ${ }^{90}$ Instead, the loony and mischievous little god falls in love with the queen himself and shoots Phaon with an arrow of spite towards Venus, who falls in utter despair after witnessing the charming boatman setting sail from Syracuse and her young child proclaiming himself Sappho's beloved son. ${ }^{91}$ In his comedy Lyly rewrote Ovid's story as an allegorical account of the actual events at the English court, with Sappho symbolizing queen Elizabeth I and Phaon representing Francis, Duke of Anjou, who for a long time courted the queen, until in 1582 he finally gave up his efforts, leaving the whole England in disappointment. Nonetheless, Lyly offered a consolation to the queen by stressing the possibility of achieving sublime and bodiless form of love, as exemplified by the relationship between Sappho and Cupid. ${ }^{92}$

In 1590, Lyly's contemporary Sir Philip Sidney published Arcadia, a tragicomic hybrid of pastoral romance and classical Greek tragedy with a plot set in the province of the ancient Peloponnese of the same name. At the end of the first of its five books, Sidney adapted Sappho's Fragment 1 into a poem about strong "sisterly" love, which the Amazon Zelmane, actually a transvestite named Pirocles, sings to the young Philoclea after saving her life from a frenzied lion. ${ }^{93}$ By setting the poem into a homoromantically fuelled moment, Sidney indeed acknowledged the artistic value of the homoerotic themes in Sappho's poetry, but he simultaneously parodied it with the fact that Philoclea does not recognize Pirocles as a transvestite and reveals her true feelings only after he discloses his gender. ${ }^{94}$ In other words, by

89 Lyly, Sapho an Phaon, I, 1, 36-37 = BEVINGTON \& HUNTER 1999: 172, Venus: Sapho shall know, be she never so fair, that there is a Venus which can conquer, were she never so fortunate; IV, 1, 2-4 = BEVINGTON \& HUNTER 1999: 182, Sapho: Oh Venus, my cares are only known to thee, and by thee only came the cause. Cupid, why didst thou wound me so deep?

90 Lyly, Sapho and Phaon, IV, 2, 5-7 = BEVINGTON \& HUNTER 1999: 179, Venus: Oh Venus! Unhappy Venus! Who in bestowing a benefit upon a man has brought a bane unto a Goddess... Oh fair Phao! And therefore made fair to breed in me frenzy!; V, 1, 17-19= BEVINGTON \& HUNTER 1999: 192, Venus: ...This arrow, sweat child...must Phao be stricken withal; and cry softly to thyself in the very loose 'Venus!'

91 Lyly, Sapho and Phao, V, 2, 41-42 = BEVINGTON \& HUNTER 1999: 199, Cupid (to Venus): I will be Sapho's son. I have, as you commanded, stricken her with a deep disdain of Phao; and Phao, as she entreated me, with a great despite of you.

92 BEVINGTON \& HUNTER 1999: 164-172.

93 Sir Phillip Sidney, Arcadia, I, 19, 8 = BEAR 2003: 141, Zelmane...thus desiring her voice shoud be accorded nothing but Philocleas eares... sange these Sapphics... Which is helde in loue, loue it is, that hath ioynde /Life to this our soule.

94 Sir Phillip Sidney, Arcadia, II, 4, 7 = BEAR 2003: 166, ... and if she can loue poor me, shall I thinke scorne to loue such a woman as Zelmane?; II, 17, 4 = BEAR 2003: 232, Behold here before your eyes Pyrocles, prince of Macedon, whome you only haue brought to this game of Fortune, and unused Metamorphosis...; II, 17, 5, True it is, alas, too true it is, o Zelmane (for so I loue to call thee, since in that name my loue first began...),...my passions were fitter to desire, than to be desired...Doust thou loue me? Keep me then still worthy to be beloued. 
personifying in Philoclea the addressee of Sapphic poetry, Sydney promoted the idea of lesbian romance as a transient, frivolous and unrealizable episode in the life of a woman, which inevitably gave way to the normative heterosexual relationship and thereby inscribed himself into the tradition that understood Sappho's sexuality through the Ovidian strategy of narrativization.

In the context of almost universal heterosexualization of Sappho in the early modern period, the late-Elizabethan poet John Donne represents a radically subversive exception. In his late $16^{\text {th }}$-century erotic elegy From Sappho to Philaenis he opposed the homophobic erasure of allusions to Sappho's homoeroticism, sporadic invocation of lesbian affectation in the works of several Pleiadian and Elizabethan authors, as well as the authority of Ovid's Heroides. By assuming the voice of the glorious poetess, not only did Donne illustrate the anatomy of unrequited passion towards another woman, but he goes a step further insofar as he depicted men as brutish and insensitive partners and heterosexual relationships as inherently oppressive. ${ }^{95}$ The subversive character of his elegy was realized in three aspects. In the first place, Donne replaced the canonized representation of Sappho as an old, unhappily enamoured heterosexual poet with the young, active and self-aware lesbian lyricist, who falls in love with another woman and manages to forget all her previous male lovers, including Phaon himself. ${ }^{96}$ Apart from that, he chose a woman as the object of Sapho's love and in this sense introduces Philaenis, who in the Renaissance philology figured as a controversial composer of pornographic poetry. ${ }^{97}$ Ultimately, in his poem Donne tackled the issue of the (im)possibility of actualizing a healthy romantic relationship between two people, since heterosexual couplings were plagued by gender inequality, while male homosexuality was proscribed within the prevailing Judeo-Christian moral framework. Faced with these limitations, he found a solution of the above-mentioned problem in the concept of lesbian love as the highest form of erotic fiction. ${ }^{98}$

Discursive strategy of narrativization experienced a real proliferation in the $17^{\text {th }}$-century French literary culture, which transformed Sappho into a symbol of tragic heterosexual love, reducing her poetry to a matter of secondary importance. In literature this approach was applied in the 1653 novel Artamenes, or Cyrus the

95 Donne, Sappho to Philaenis, lines 5-6 = MUELLER 1992: 133, Have my tears quench'd my Poetique fire ; / Why quench'd they not as well, that of desire?; lines 57-58 = MUELLER 1992: 134, $O$ cure this loving madnesse, and restore / Me to mee; thee, my halfe, my all, my more; lines 38-40 = MUELLER 1992: 134, ... why shoulds thou than / Admit the tillage of a harsh rough man? / Men leave behinde them that which their sin showes, / And are, as theeves trac'd, which rob when it snows.

96 Donne, Sappho to Philaenis, lines 25-26 = MUELLER 1992: 133, Such was my Phao'awhile, but shall be never, / As thou, wast, art, and, oh, maist be ever.

MUELLER 1992: 110.

MUELLER 1992: 112-115. 
Great by the French salonnière and feminist writer Madeleine de Scudéry, who used famous figures and stories of antiquity as an allegory of contemporary public persons socio-political problems. In the last of her ten tomes, de Scudéry reinscribed Ovid's $15^{\text {th }}$ Heroide as a happy-end story of love between Sappho and Phaon, representing the poetess as the ideal of an emancipated, enlightened and unpretentious feminist of her time and the ferryman as a perfect man who recognizes and appreciates these qualities in a woman. ${ }^{99}$ In doing so, she constructed a vision of a utopian, sincere and respectful heterosexual partnership and criticized the mechanisms of heteropatriarchal oppression which in reality rendered such relationships impossible. ${ }^{100}$ In $17^{\text {th }}$-century French philology the key-role in the popularization of the narrativization strategy was played by Madame Dacier, a pseudonym of the classical scholar Anne Le Fèvre, who in her 1682 translation of Sappho's and Anacreon's poetry retrieved information from the Suda and Ovid, representing Sappho as an aged widow who declines the proposals of numerous suitors and falls in love with the disinterested young Phaon. This ultimately leads her to commit suicide by leaping off the precipice of Leucas. Dacier additionally dismissed Ovid's reports about the poetess' homosexual past as perfidious rumours of ancient authors who were envious of Sappho's brilliance. ${ }^{101}$ Apart from Pierre Bayle, whose 1695 philological study in agreement with Ovid treated Sappho's homosexual behaviour as an unruly transgression of her troublesome youth, finally atoned by her love for Phaon later in life, the majority of European literati of the late $18^{\text {th }}$ century in their reception of Sappho followed the model established by Dacier by either denying or turning a blind eye to every mention of the poetess' homosexuality.

Convincing example of Dacier's European authority in the $18^{\text {th }}$ century are works of the English writer Mary Robinson, also known as "the English Sappho". ${ }^{102}$ For one thing, in her 1796 collections of sonnets titled Sappho and Phaon she assumed the voice of the ancient poetess to communicate the unrequited love for the ferryman in terms of melancholic resignation from every reason and philosophy,

99 Madeleine de Scudéry, Artamène ou le Grand Cyrus X, 2, 345 = SCUDÉRY 2018: 6916, mais encore une fois, dés que je les regarde comme Maris, je les regarde comme des Maistres : et comme des Maistres si propres à devenir Tirans, qu'il n'est pas possible que je ne les haïsse dans cét instant là : et que je ne rende graces aux Dieux de m'avoir donné une inclination fort opposée au Mariage; X, 2, 504 = SCUDERY 2018: 707:, Jamais l'on n'a về deux coeurs si unis : et jamais l'Amour n'a joint ensemble tant de pureté, et tant d'ardeur.

100 SCHLESIER 2013: 846.

101 LE FÈVRE 1716: 233-237, Elle fut mariée à un des plus riches homes del'Isle d'Andros, nommé Cercala...eut une fille quel'on appella Cleïs...elle etoit meme fort au dessus des plus exellens Poetes... ...elle ne fut pas exempte de passion, tout le monde sait qu'elle aima Phao...qu'elle $s$ 'en alla en Acarnanie au promontorie de Leucade,...elle se precipita dans le Mer \& mourut... au reste, quoi que je sois persuadee qu'il y a eu beaucoup de medisance dans tout ce que l'on a dit contre Sapho, je ne crois pas pourtant qu'elle ait ete d'une sagesse exemplaire.

102 TY 1997: 32. 
which culminates in the jump into the sea washing the shores of Leucas. ${ }^{103}$ For another thing, in her novel The False Friend: A Domestic Story the protagonist Gertrude St. Leger sees Sappho as a symbol of ingenuous women who ended up tragically as victims of their uncontrolled love for unscrupulous men, ${ }^{104}$ a destiny she ultimately shares with her well-versed late mother, whose physiognomy was taken as a model for a bust of Sappho decorating the hall of Denmore Castle, ${ }^{105}$ as well as with her stepmother Lady Denmore, who presumably plays the harp. ${ }^{106}$ The presence of Dacier's paradigm is also discernible in the 1781 novel Adventures of Sappho, the Poetess of Mytilene by the Italian writer Alessandro Verri, whose plot revolves around Sappho's unreturned passion for Phaon, himself enamoured with the common girl Cleonice. ${ }^{107}$ In his novel Verri reduced Sappho's poetry to a mere consequence of her passion, ${ }^{108}$ while her homosexual liaisons were declared an insolent calumny of her invidious contemporaries. ${ }^{109}$ Although today largely forgotten, during the $18^{\text {th }}$ and $19^{\text {th }}$ centuries the novel attracted a wide audience, saw five Italian reprints and numerous translations in other languages ${ }^{110}$ which

103 ROBINSON 1796: XVIII, lines 1-2, Why art thou chang'd? O Phaon! tell me why? / Love flies reproach, when passion feels decay; XXV, lines 9-14, Oh! Sov'reign of my heart! return! return! / For me no spring appears, no summers bloom, / No Sun-beams glitter, and no altars burn!; XLII, lines 5-8, Soon o'er this heart, now warm with passion's flame, / The howling winds and foamy waves shall sweep; / Those eyes be ever clos'd in death's cold sleep, / And all of Sappho perish, but her name!

104 ROBINSON 1799: I, 165-166, The Grecian poetess...was not famed for personal attractions: she was, like many children of genius, equally distinguished for the gifts of mental preeminence, and the persecutions of misfortune...;I, 296, In vain I endeavour to analyze my feelings: they are complicated to the verge of insanity.

105 ROBINSON 1799: IV, 253... a bust, after the model of the Grecian Sappho...it was cast from her features...

106 ROBINSON 1799: II, 315-316, ...she was a victim of an unconquerable passion; the susceptibility of her mind was the ruin of her prospects, the bane of her reputation and the undermining poison of her repose forever...she sacrificed all that was dear in a woman, for a wretch who was deeply practised in all that was despicable in a man; I, 281,... I fancied I could hear her pulsation, when a large string of Lady Denmore's harp suddenly broke.

107 VERRI 1793: 97, Ah madre, esclamò Saffo! io non posso vivere senza di lui, che già è il tiranno dell'anima mia...; 136, ...Faone era partito per la Sicilia per faccende mercantili, terminate le quali, avea già data la fede di celebrare le nozze a Cleonice...

108 VERRI 1793: 216, ...si aggiungeva a questo fallace conforto anche l'assenza dell'oggetto amato...compose nel silenzio della notte quel celebrato Inno a Venere.; 219, ...che fece ragionevolmente credere, che quento Venere le era contraria, altretanto le fossero favorevoli le Muse; e però stimolata non meno dalle ripetute lodi...esalando in lamenti poetici...compose quell'altra sua chiarissima Ode a Faone.

109 VERRI 1793: 220, ...Ode a Faone, ben so che altri asseriscono dedicata ad una fanciulla da lei amata con disidicevole delirio. E tanto crebbe questa fama contraria al nome di così leggiadro ingegno (forse promossa della invidiosa malignità de' garulli Poeti) che fu asserito da taluni...che ella fosse stata imersa in dissoluti costumi a segno che le rimanesse l'ignominioso titolo de Tolßás.

110 MOST 1995: 16. 
strengthened Ovid's authority in assessing Sappho's sexuality. Another example of this trend can be observed in a piece of adventure fiction similar to Verri's, which came from the pen of French novelist Jean-Jacques Barthélemy. In his Travels of Anacharsis the Younger in Greece Barthélemy took on the voice of the 4th-century fictional Scythian hero Anacharsis and represented Sappho as the greatest poetess of antiquity, who after the death of her husband repudiated her life to writing and teaching young women the art of poetry. ${ }^{111} \mathrm{He}$ repudiated every claim about Sappho's involvement in homoerotic relationships, stating that she was united with her pupils only by asexual Platonic love. ${ }^{112}$ Barthélemy's account on Sappho finished with the moment of her tragic leap from Leucas, following her romantic disappointment with Phaon, ${ }^{113}$ with which he indubitably subscribed to the tradition of Sappho's reception that rested on Ovidian strategy of narrativization.

\section{Herois romantica et tribas decadens. $19^{\text {th }}$-century Sappho.}

The approach of romanticist literature to Sappho is characterized by the introduction of a new paradigm, based on the discursive strategy of condensation. It restored the central importance of Sappho's poetic activity and constructed a paradoxical persona of an emotionally and cognitively transcendent poetess who writes her exquisite verses with the purpose of escaping the suffocating constraints of corporeal life and achieving spiritual perfection in an ethereal form of love, which necessitates suicide as the only solution of these unendurable contradictions. ${ }^{114}$ In this context Sappho's sexuality ceased to present an issue, since the poetess invariably started to figure as an epitome of tragic heterosexual love. The theoretical foundations for the discursive strategy of condensation were laid in the 1794 literary-theoretical study On the Borders of the Beautiful by the German philosopher Friedrich Schlegel, who represented the Lesbian poetess as a soul gifted with sublime emotional capacities, trapped within the carnal world of material and libidinous desires, from which she finally fled by murdering her bodily-self. ${ }^{115}$ Schlegel's model was adopted

111 BARTHÉLEMY 1826: 75, Après la mort de son époux, elle censacra son loisir aux lettres, dont elle entreprit d'inspirer le goût aux femmes de Lesbos. Plusieurs d'entre elles se mirent sous sa conduite...

112 BARTHÉLEMY 1826: 75, Lisez les dialogues de Platon; voyez en quels termes Socrate y parle de la beauté de ses élèves. Cependant Platon sait mieux que personne, combien les intentions de son maitre étaint pures. Celles de Sapho ne l'étaient pas moins peut-être...

113 BARTHÉLEMY 1826: 77, Elle aima Phaon dont elle fut abandonnée: elle fit de vains efforts pour le ramener; et désaspérant d'être désormais heureuse avec lui et sans lui, elle tenta le saut de Leucade, et périt dans les flots.

114 MOST 1995, 21-22.

115 SCHLEGEL 1979: 41-43, Überhaupt ist Reizbarkeit das gefährlichste wie das schönste Geschenk der Götter. Setzt in einem Gemüt die Empfänglichkeit sehr gering, die Reizbarkeit so grenzenlos, daß die leiseste Berührung ihre ganze Schnellkraft anregt; die Selbsttätigkeit sei 
and developed in almost all later romanticist reinventions of Sappho, of which the most representative are Sappho: Ancient Elegy by the French poet Alphonse de Lamartine of 1815, Sappho: Tragedy in Five Acts by the German dramatist Franz Grillparzer published in 1817 and The Last Poem of Sappho by the Italian poet Giacomo Leopardi published in 1822.

The condensation of Sappho's persona in Lamartine's elegy is accomplished through the tragic solution of the conflict existing between two principal parts of her identity: that of a poet and that of a lover. The poem is written in the form of Sappho's appeal before the terrified maidens of Lesbos moments before her fatal leap and describes how her verses have managed to conquer the hearts of whole Greece, except the heart of the only person she desired to fascinate: Phaon. ${ }^{116}$ Thus, in spite of achieving the actualization of her poetic identity, Sappho's romantic self suffers complete disintegration. Unable to survive without complete selfactualization, she destroys her lyre as a symbol of her poetic self and performs her last song as a farewell to her earthly existence, before finally perishing in the sea underneath the promontory of Leucas. ${ }^{117}$

The same conflict between the poetic and the erotic self forms the axis of the plot in Grillparzer's tragedy, except that it serves as an instrument to articulate in even deeper tension between individual's desire for self-determination, on the one hand, and the need for social integration, on the other hand. In order to communicate this idea, Grillparzer first exaggerates Sappho's creative accomplishment by introducing the plot in the moment of her triumphant return to Lesbos from the poetic competition at the Olympics Games. ${ }^{118}$ However, the victor's laurel wreath

so stark, daß sie die Herrlichkeit des Lebens mit der Reizbarkeit teile. Sein Dasein würde ein stetes Schwanken sein, wie die stürmische Woge; - eben schien sie noch die ewigen Sterne zu berühren, und schon stürzte sie in den furchtbaren Abgrund des Meeres. Diesem Gemüte die aus der Urne des Lebens das höchste und das tiefste im Überfluß von Harmonie unendlich zerrissen. So denkt euch die Sappho, und alle Widersprüche in den Nachrichten über diese größte aller Griechischen Frauen sind erklärt.

116 LAMARTINE 1963: 114, lines 2-33, 5-6, 14-15, Ainsi parla Sapho debout sur le rivage, / Et près d'elle, àgenoux, les filles de Lesbos /...Fatal rocher, profond abîme! / Je vous aborde sans effroi! .... On dit que dans ton sein...mais je ne puis le croire! / On échappe au courroux de l'implacable Amour /; 115, lines 60-64, Je composai pour lui ces chants pleins de douceur, / Ces chants qui m'ont valu les transports de la Grèce: / Ces chants, qui des Enfers fléchiraient la rigueur, / Malheureuse Sapho! n'ont pu fléchir son coeur, / Et son ingratitude a payé ta tendresse!

117 LAMARTINE 1963: 116-117, lines 1300-134, Ô lyre! que ma main fit résonner pour lui, / Ton aspect que j'aimais m'importune aujourd'hui, / Et chacun de tes airs rappelle à ma mémoire / Et mes feux, et ma honte, et l'ingrat qui m'a fui! / Brise-toi dans mes mains, lyre à jamais funeste!

118 GRILLPARZER 1947: 139, RHAMNES:...Sie kehrt von Olympia, hat den Kranz, / Den Kranz des Sieges hatsie sich errungen / Im Angesicht des ganzen Griechenlands / Als Zeugen edlen Wettkampfs dort versammelt. 
is of little significance to the poetess, who feels that her creative overachievement and peerlessness isolate and alienate her from the common folk, unable to comprehend her emotional and spiritual supremacy, as well as from her beloved Phaon, an attractive and pure-hearted, but simple-minded youth, incapable of reciprocating her sublime form of love. ${ }^{119} \mathrm{He}$ eventually falls in love with Sappho's unsophisticated slave girl Melitta, which prompts the desperate poetess to realize the incompatibility of her exalted spirit with the earthly world of superficial passions. ${ }^{120}$ In the effort to liberate herself from the feeling of unconformity, she commits suicide and transports her spirit into the perfect, ethereal world of gods, where it belongs. ${ }^{121}$

The mind-body dialectic provides the basis for condensation of Sappho's character in Leopardi's ode: while her spirit is sublime, noble and fed solely by bodiless form of love, her body does not correspond with the worldly conventions of beauty. Striving to fulfil her need for beauty, Sappho falls in love with handsome Phaon, who, however, rejects her body as unappealing, which induces in her a triangular conflict between the inclination towards everything beautiful, such as Phaon and nature, aversion towards anything perceived as ugly, like her own body, and the desire to find happiness and beauty beyond carnal reality. ${ }^{122}$ Her creative ingenuity is at odds with her romantic disappointment, which ultimately leads her to the realization that the source of her anguish lies in the embodiment within the world of shallow bodily urges. Hence, the suicide of Leopardi's Sappho does not aim at bringing an end to the suffering caused by unrequited love, but rather at releasing the perfect spirit from ailing shackles of carnality. ${ }^{123}$

119 GRILLPARZER 1947: 142, SAPPHO:...Ja, meine Freunde, mögt ihr's immer wissen, / Ich liebe ihn, auf ihn fiel meine Wahl. / ...An seiner Seite werd' ich unter euch / Ein einfach stilles Hirtenleben führen; / Den Lorbeer mit der Myrte gern vertauschend /; 147, PHAON:...Wer glaubte auch, daß Hellas ' erste Frau / Auf Hellas 'letzten Jüngling würde schauen!

120 GRILLPARZER 1947: 167, SAPPHO: Von all den Mädchen, / Die je ein teurer mir als sie, Melitta, / Das liebe Mädchen mit dem stillen Sinn. / Obschon nicht hohn Geists, von mäß'gen Gaben / Und unbehilflich für der Künste Übung /; 206, PHAON:...Du warst-zu niedrig glaute dich mein Zorn, / Zu hoch nennt die Besinnung dich - für meine Liebe. / Und nur das Gleiche fügt sich leicht und wohl!

121 GRILLPARZER 1947: 217, SAPPHO:...So zahle ich die letzte Schuld des Lebens! / Ihr Götter, segnet sie und nehmt mich auf!...RHAMNES....Es war auf Erden ihre Heimat nicht / ...Sie ist zurückgekehrt zu den Ihren!

122 LEOPARDI 2006: 237-238, lines 37-44, Qual fallo mai, qualsì nefando eccesso / Macchiommi anzi il natale, onde si torvo / Il ciel mi fosse e di fortuna il volto? / In che peccai bambina, allor che ignara / Di misfatto è lavita, onde poi scemo / Di giovanezza, e disfiorato, al fuso / Dell'indomita Parca si volvesse / Il ferrigno mio stame?

123 LEOPARDI 2006: 239, lines 70 - 2, Il Tartaro m'avanza; e il prode ingegno / Han la tenaria Diva, / E l'atra notte, e la silente riva. 
A new paradigm in articulating Sappho's sexuality was set forth by modernist discourse in Western literature, which for the first time in history audaciously drew inspiration from homoerotically connoted Sappho's fragments and constructed the poetess as a morbid and decadent tribade. The most important representative of this shift in reception is Charles Baudelaire, who in the scandalous tradition about Sappho's promiscuity and homoeroticism recognized potent material for decadent reinvention, which he put into effect in his famous 1857 masterpiece collection The Flowers of Evil. In one of its poems, titled Lesbos, Baudelaire represented the Aeolian island as an immoral and anti-Platonic homeland of licentious beauties resembling the famed Greek courtesan Phryne, imagining himself as a watchman at Leucas who anticipates the casting ashore of Sappho's mutilated corpse. ${ }^{124}$ In 1884, inspired by Baudelaire's reinvention of Sappho as a satanic tribade, Alphonse Daudet wrote his novel Sappho, in which the name of the poetess, with its promiscuous and homoerotic connotations, became the pseudonym of the main antagonist Fanny LeGrand, a self-seeking and manipulative femme fatale, who seduces the Parisian artists and wreaks havoc in the life of the protagonist Jean Gaussin. ${ }^{125}$ Further development of Baudelaire's decadent Sappho was undertaken in the Victorian English literature, above all in the poetry of Algernon Charles Swinburne. In his 1866 collection of decadent poetry titled Poems and Ballads he rewrote Sappho's poetry as a ventriloquist and sadomasochist language of lesbian affectation, most clearly observed in the poem Anactoria, actually an adaptation of Sappho's Fragment 31 , where the voice of the poetess juxtaposes the notions of sexuality and violence by communicating tantalizing manifestations of unreciprocated love together with threatening homicidal ideation addressed to the girl who spurned her love. ${ }^{126}$ Another of Swinburne's poems from the same collection bears the title Sapphics and was intended as an homage to the poetess of Lesbos, praising her as the tenth Muse and evoking the themes and symbols of her poetry through

${ }_{124}$ BAUDELAIRE 1857: 187-190, lines 11-2 Lesbos, où les Phrynés l'une l'autre s'attirent, / Où jamais soupir ne resta sans écho; 16-19, Lesbos, terre des nuits chaudes et langoureuses, / Caressent les fruits mûrs de leur nubilité; 50-57, Et depuis lors je veille au sommet de Leucate, / Pour savoir si la mer est indulgente et bonne, / Et parmi les sanglots dont le roc retentit / Un soir ramènera vers Lesbos, qui pardonne, / Le cadavre adoré de Sapho, qui partit.

DAUDET 1884: 90, Et les caresses perverses si longtemps retenues, tous ces mots de délire de ses dents serrées arrêtaient au passage, elle les lâchait à présent, s'étalait, se livrait dans son plein de courtisane amoreuse et savante, dans toute le gloire horrible de Sapho.

126 SWINBURNE 1866: 65, lines 1-4, My life is bitter with thy love; thine eyes / Blind me, thy tresses burn me, thy sharp sighs / Divide my flesh and spirit with soft sound, / And my blood strengthens, and my veins abound; 66, lines 26-31, I would my pain could kill thee; I am satiated / With seeing thee live, and fain would have thee dead. / I would earth had thine body as fruit to eat, / And no mouth but some serpent's found thee sweet. / I would find grievous ways to find thee slain, / Intense device and superflux of pain. 
twenty Sapphic stanzas. ${ }^{127}$ Its title soon became a synonym for painful lesbian love and was appropriated as such with pride by the fin de siècle suffragettes and early feminist writers. ${ }^{128}$

In accordance with emphasizing Sappho's homosexuality in literature, the $19^{\text {th }}$ century philological discourse was marked by the flourishing of debates on Sappho's same-sex liaisons, which were nevertheless still accompanied by homophobic moralizing interventions. This is clearly observed in the 1816 study Sappho Freed from a Reigning Prejudice by the renowned German philologist Friedrich Gottlieb Welcker, who in his biographical account on the Lesbian lyricist dismissed all accusations of homosexual affinity in order to save her reputation as an exemplary and chaste mother, as well as to promote German philology as a relevant, methodologically sophisticated and morally correct scientific discipline. ${ }^{129}$ In order to execute this task, he first compiled numerous ancient and later accounts on Sappho's sexuality and evaluated their plausibility, whereupon he resorted to the old discursive strategy of duplication by claiming the existence of a fictional courtesan, ridiculed by Attic comedy, and of a splendid poetess and mentor of young lyricists, with whom she cultivated exclusively Platonic love and who eventually jumped to death because of the emotionally unresponsive Phaon. ${ }^{130}$ Another big name of the German philology of the Vormärtz period, Karl Ottfied Müller wrote his 1840/1 synthesis under the title The History of Greek Literature, in which he treated the stories about Sappho's promiscuity as an unfortunate consequence of misunderstanding of the more loose Aeolian gender roles on part of the rather conservative Athenian Ionians and additionally dismissed the story about Phaon as a legend. Nonetheless, he viewed Sappho's poetry as either an expression of unhappy love towards an anonymous man or of a merely asexual friendly affection for girls she coached in the art of poetry. ${ }^{131}$ Apart from this, in his main

127 SWINBURNE 1866: 235, lines 25-30, Ah the singing, ah the delight, the passion! / All the Loves wept, listening; sick with anguish / Stood the crowned nine Muses about Apollo; / Fear was upon them, / While the tenth sang wonderful things they knew not. / Ah the tenth, the Lesbian!

SCHLESIER 2013: 850-852.

129 MOST 1993: 25-27.

130 WELCKER 1816: 29...bei den Griechen ein so unnatürliche geheime Wollust nicht mehr als sonst irgendwo zum Gegenstand auch der freyesten Dichtkunst werden konnte ...;62,...die Lesbischen Jungfrauen auf Veranlassung eines Testes Gesang und Dichtkunst übten, so daß Sappho selbst als Zöglingin gewissermassen einer einheimischen unter dem Volk bestehenden Schule betrachtet werden könnte...;76, Daß weder in den Gedichten der Sappho, noch in der öffentlichen Kunde etwas gewesen, daß einen verdächtigen Ruf hätte begründen, oder nur der Verläumdung einigen Schein vor überlegt Urtheilenden geben können ...;94-96, ...daß die Griechen selbst, als welche ein Zerrbild als Zerrbild zu nehmen mußten, wenn sie von ihr reden, jede Beziehung auf die Sappfo der Komödie, als eine ganz andre als die wirkliche, ausschließen...

131 MÜLLER 1875: 290, Indes hätte Sappho niemals ihrem Bruder seinen Umging mit einer Hetäre vorgeworfen können, wenn sie selbst früher das Leben einer Hetäre geführt hätte..; 297, Aenliche Verbindungen bestanden in den Zeiten der Sappho zu Lesbos, nur dass sie ganz Sache der freien Neigung und Anschliessung waren, indem an Frauen, welche durch musische Kunst, feine 
work from 1861, titled The Matriarchy, Johann Jakob Bachofen restored Sappho's morality from the perspective of the history of religion. He claimed that Sappho's tutorship of young women represented some sort of orphic and mystic practice which celebrated feminine beauty rather than promiscuous homosexuality. ${ }^{132}$ Taking a stance moderately diverging from his three aforementioned colleagues, Scottish philologist William Mure in A Critical History of the Language and Literature of Antient Greece, published in 1854, saw Sappho as the head of a community of women, whom she provided with music lessons and some sort of sexual education. ${ }^{133}$ Although he followed Müller and Bachofen in ascribing the fictional status to the story of Sappho's Leucadian leap, Mure read her epithalamia and Fragment 1 as an expression of heterosexual promiscuity and interpreted Fragment 31 as a proof of Sappho's "impure intercourses" with other women. ${ }^{134}$

Tribadum herois, magistra, coryphea, sacerdos, conviva? Contemporary Sappho.

In the late $19^{\text {th }}$ and early $20^{\text {th }}$ centuries, the debates on Sappho's sexuality initiated by Welcker and Müller triggered the final unmasking of Sappho's poetry

Bildung und Liebeswürdigkeit des Betragens sich auszeichneten, Mädchen sich anschlossen, die derselben Art von Bildung nachstrebten..; 293, Dass Sappho in ihren Liedern öfters eines Jünglings gedachte, während er sie mit kalter Gleichgültigkeit betrachtet, ist sicher..; 299, So und mit nich stärkeren Zügen schildert die Dichterin nichts als eine freundliche Zuneigung zu einem jüngeren Mädchen, die indess bei der grossen Reizbarkeit aller Gefühle den Ton der glühendsten Leidenschaft annimmt.

BACHOFEN 1897: 237, Hat Sappho an der Spitze der auserwählten Dichterinnen gegen Nichts so sehr geeifert als gegen die hetärische Entartung des Daseins und in ihren Epithalamien den reinern Gedanken der orphisch-dionysischen Religion als Mittelpunkt des höhren weiblichen Lebens festgehalten, so ist doch gerade Lesbos dem Hetäirismus und seinem ganzen Verderben in besonderem Grade zur Beute geworden.

133 MURE 1854: 279,... a number of females of tastes and pursuits akin to her own, who formed an association or club of ladies devoted to the pursuit of every species of refined and elegant pleasure, sensual or intellectual.

134 MURE 1854: 280, Both these points in the history of the poetess, her love for Phaon and her leap from the Leucadian cliff, have been questioned, with more or less plausibility, by distinguished critics of the present age; 308-309, In closer illustration of the spirit of her amorous muse, attention may be directed to the first ode in the existing collection... and few probably who have perused it with unprejudiced minds... have discovered in its glowing energy of voluptuous expression, any symptoms of that maiden modesty which the more ardent admirers of its author pronounce to have been one of her most prominent characteristics...And this, we are told, is the language of an innocent virgin, or a virtuous matron; $315-317, \ldots$ the taste for impure intercourse, which forms so foul a blot on the Greek national character, was not confined to the male sex; and that, among females who had the chief credit with being infected with that taste, the Lesbians were so remarkable, as to have procured for it...the distinctive title of the Lesbian vice...In several places Sappho addresses certain of her female associates in terms of no less voluptuous passion than those employed towards her male objects of affection. 
as a "Trojan horse" in the history of Western literature. The turning point in this sense occurred in the year 1894, when the French poet Pierre Louÿs published his Songs of Bilitis, a collection of lesbian poems attributed to the fictional courtesan and Sappho's contemporary Bilitis. ${ }^{135}$ By convincingly mimicking the poetic style of Sappho and epigrams contained within The Palatine Anthology and by inventing historical records about the life of Bilitis and subjecting them to a thorough critical analysis of fictitious German archaeologist Herr G. Heim ("Mr. C. Cret"), ${ }^{136}$ Louÿs gave his fabrication such a plausible appearance that it managed to deceive even the most competent European philologists for well over a decade. ${ }^{137}$ Even though ultimately exposed as fraudulent, Louÿs' work intensified the association of Sappho's name with the idea of female homosexuality, which in turn led the early $20^{\text {th }}$-century Western feminist and lesbian writers to solve the raging issue of deficient female literary tradition by proclaiming Sappho's poetry the earliest expression of feminist and lesbian consciousness in the history of Western literature and thereby to promote the female and lesbian as the principal characteristics of that poetry. ${ }^{138}$ Previously the tenth Muse, licentious hetaira and tragic heterosexual heroine thus experienced her most recent and consequential reinvention, becoming the first feminist and lesbian in Western history, as well as the symbol of all female literary geniuses accidentally or intentionally erased from historical record.

Tropes pertaining to the process of transforming Sappho's poetry into the starting point of feminist literary tradition are plainly noticeable in the works of Virginia Woolf. Her 1921 short story A Society describes the research and discussion of an informal community of subversive female intellectuals about how motherhood represented a significant historical impediment to their actualization as writers and perpetuated male domination over literary production. ${ }^{139}$ One of the

35 LOUŸS 1913: 6, Alors Sapphô était ancore belle. Bilitis l'a connue, et nous perle d'elle sous le nom de Psappha qu'elle portait à Lesbos; 10, Elle fout courtisane, cela n'est pas niable...

136 LOUŸS 1913: 3, Elle avait à peine seize ans, selon les conjectures de M. Heim qui établit avec vrai semblance quelque dates dans la vie de Bilitis...; 106, Elle entra, et passionément, les yeux fermés à demi, elle unit ses lèvres aux miennes et nos langues se connurent...Jamais il n'y eut dans ma vie un baiser comme celui-là; 108, Le matin, on fit le repas de noces, dans la maison d'Acalanthis qu'elle avait adoptée pour mère. Mnasidika portait le voile blanc et moi la tunique virile; 120, Avec soin, elle ouvrit d'une main sa tunique et me tendit ses seins tièdes et doux, ainsi qu'on offre à la déesse une paire de tourterelles vivantes; 127, Alors (et c'estun de ses jeux) elle glisse sa petite tête par-dessous et imite la chevre autremblant qui s'allait au ventre de sa mère.

137 HALLETT 1979: 451.

138 GUBAR 1984: 46.

139 WOOLF 2011: 6, ,I, for one, have taken it for granted that it was a woman's duty to spend her youth in bearing children... While we have born the children, they (men), we supposed, have borne the books and pictures. We have populated the world. They have civilized it." 
participants illustrates this problem by drawing attention to an edition of Sappho's poetry by a fictional Oxbridge professor Hobkin, who employed all his knowledge and reasoning capacities in the effort to represent the poetess as a chaste wife and mother, which provokes the counterargument of another participant in the discussion, who cites a newspaper article stating that "since Sappho there's been no female writer of first rate". ${ }^{140}$ Similar statement is repeated in The Room of One's Own, where Woolf refers to Sappho as "an inheritor as well as an originator" of Western women's literature. ${ }^{141}$ Therefore, in the two mentioned works Woolf pointed to the irreconcilability between the feminist essence of Sappho's poetry and its heteropatriarchal interpretation from the pen of male literary critics, thus communicating two important ideas. On the one hand, she cautioned that the heteropatriarchal gender roles historically suffocated the capacity of women to establish themselves as writers with their own literary tradition. On the other hand, she presented Sappho as the earliest example of a female writer who, due to the specific circumstances related to the social status of women on ancient Lesbos, managed to overcome these limitations, thereby suggesting her poetry as a potential point de depart of feminist literary tradition. ${ }^{142}$

The reinvention of Sappho as the first lesbian within the Western literary canon is possible to examine in the works of three Anglo-American writers from the beginning of the $20^{\text {th }}$ century: the late-Victorian British poetess Reneé Vivien, American imagist writer Hilda Doolittle and her colleague Amy Lowell. In 1903, Vivien, inspired by the style of symbolist, Parnassian and decadent movements, as well as by the tribulations of her dysfunctional relationship with the American dramatist Natalie Clifford Barney, published her poetry collection Sappho, furnishing it with the hitherto known originals of Sappho's fragments, their French translations, as well as her own creative reconstructions of lost verses, imbued with strong homoerotic sentimentality. ${ }^{143} \mathrm{~A}$ year later, during her stay at Mytilene, she wrote roman à clef

140 WOOLF 2011: 7-8, ,, when Professor Hobkin was out, I examined his life work, an edition of Sappho...Most of it is a defence of Sappho's chastity, which some German had denied...; 11, „Since Sappho there's been no female of first rate - ,. Elanor began, quoting from a weekly newspaper. „It's now well known that Sappho was the somewhat lewd invention of Professor Hobkin, "Ruth interrupted. „Anyhow, there is no reason to suppose that any woman ever has been able to write or ever will be able to write, "Eleanor continued.

141 WOOLF 2015: 79, Moreover, if you consider any great figure of the past, like Sappho...you will find that she is an inheritor as well as an originator, and has come into existence because women have come to have a habit to write naturally;...

142 GUBAR 1984: 45.

143 VIVIEN 1903: 8, Qui te fair souffrir del'àpre convoitise? / Et quelle Peithò plus blonde qu le jour / Aux cheveux d'argent te trahit et méprise, / Psappha, ton amour?; 46, Les avante ardeur de autumne recèle / Dans ta nudité le sambres et les ors. / Tu gardes, ò vierge inaccessible et belle / Le fruit de ton corps.; 93, Nous ne craignons point, Atthis, ò ma Maítresse! / L'ombre du trépas. 
titled $A$ Woman Appeared to Me, in which she portrayed Sappho as an exceptional poetess and the head of a cult celebrating lesbian love, who did not bother with the existence of men, wherefore the envious and misogynistic ancient comic writers invented the story of her suicide because of Phaon. ${ }^{144}$ In her sapphistries Vivien simultaneously adhered to Baudelaire's and Swinburne's model of Sappho as a decadent femme fatale and opposed their homophobic voyeuristic and ventriloquist discourse in order to reclaim decadence as an essentially lesbian literary tradition. ${ }^{145}$

Like Vivien, Doolitle, who wrote under the initials H.D., rewrote Sappho's poetry as a postmodern poetical language of female and lesbian affectation. The first chapter of her 1926 novel Palimpsest is set in ancient Rome and introduces the protagonist Hipparchia, translator and imitator of a fictional Greek poetess Moero, ${ }^{146}$ whose poetic style irresistably resembles that of Sappho. ${ }^{147}$ However, unlike Vivien's lesbian, who resembles a sufferer of borderline personality disorder, Hipparchia figures as cynical, emotionally complex and industrious scholar who seeks to escape the disappointing superficiality of male company by devoting herself fully to discovering the perfection of lyric expression. ${ }^{148}$ Apart from Palimpsest, Doolittle wrote a poetry collection Hymen, where she reinvented five Sappho's erotica and epithalamia in an imagist tone, which stand in contrast to Vivien's unrestrained homoeroticism by silencing the homoerotic vibrations in order to remain as faithful as possible to their ancient inspirator. ${ }^{149}$ What is even

144 VIVIEN 1905: 2, Lorély est la prêtresse païenne d'un culte ressuscité, la prêtresse del'amour sans époux et sans amant, ainsi quele fut jadis Psappha...Elle t'enseignera l'immortel amour des amies.; 56-57, Je vous apportais, moi, le songe, dans mes mains creusées à la façon des coupes. L'homme que vous éspouserez ne peut vous que des réalités...Et quelles hideuses, quelles sordides réalités!...Mais vous préférez laréalité ausonge. Allez vers votre destin. Vous avez voulu la médiocrité et la laideur...Vous avez appelé le mariage et la maternité.

145 GUBAR 1984: 47-52.

146 DOOLITTLE 1968: 71-72, Hipparchia was building, or rather further ornamenting his already perfect background. Her work was a correlation of gods, temples, flowers, poets... Her book was a fervid compilation of poetry, religion and ethics... The translation in the heavier language felt faulty, repetitive. It was as if a light that had been burning in clear agate was set now in granite...Moero was alabaster ane her spirit was pure fire...Sappho in Latin. It was absolute desacration. It was desacration to translate it.

147 DOOLITTLE 1968: 77, You rest upon a golden bed,/In Aphrodite's golden house, / O grape, O cluster cold and pure / your blood is honey, spirit-fire.

148 DOOLITTLE 1968: 74-75, Marius had betrayed her... But betrayal so far helped her. Hipparchia did not stay with Verrus. Stronger than the body, the mind held eminence...Mind and mind. She tought of... intimacy without intercourse...Romans were too crude... There were similar signs all about her, that the Romans were indubitably stupid.

149 DOOLITTLE 1983: 131-132, Not honey, / not the plunder of the bee / ... not iris - old desire - old passion - old forgetfulness - old pain / not this nor any flower / ...neglect the lyre-note / knowing that you shall feel, / about the frame, / no trembling of the string / but heat, more passionate / of bone and the white shell and fiery tempered steel.; 165-166, I know not what to do- / My mind is reft. / Is song's gift best? / Is love's gift loveliest? / ... So shall I take you? / My mind is quite divided; / My minds hesitate / So perfect matched / I know not what to do. 
more surprising, considering Doolittle's status as a lesbian writer, is the fact that her works posit a male body as the object of protagonist's erotic desire. ${ }^{150}$ However, as Gubar perceptively notices, these heterosexual liaisons without exception emerge as an impediment to the creative development of a female speaker by making her unhappy, lonely and misunderstood, which Doolittle uses to imply lesbianism as the only way of emancipation from oppressive heterosexuality and to suggest Sappho as her literary foremother, ${ }^{151}$ which she confirms in her essayist works. ${ }^{152}$

Finally, Amy Lowell assumed a much more critical stance than Vivien and Doolittle in her contemplation of Sappho's work as the seed of European lesbian literature. Considering the underrepresentation of women in the Western literary history and the subversive potential of Sappho's poetry, in 1926 Lowell wrote her poem Sisters, in which she reflected upon the question of the correspondence between the contemporary representation of Sappho as the oldest lesbian writer and the possible ways in which the ancient poetess understood her own professional and sexual identity. To provide an answer to this dilemma, she imagines a conversation with Sappho during which she realizes the difference between the openness of her own and the subtlety of Sappho's homoerotic lyric language, which ultimately leads her to conclude that, due to the enormous gap in their respective historical and cultural contexts, she will never be able to find a common language with the ancient poetess. ${ }^{153}$ To put it differently, Lowell was aware of the fact that contemporary lesbian writers would never manage to establish a direct intertextual communication with Sappho, without reshaping the original meaning of her poetry according to their own position of subjectivity. This self-criticism became a paradigm in the reinvention of Sappho in all future generations of feminist and lesbian

150 DOOLITTLE 1983: 173, Keep love and he mocks, / ah, bitter and sweet, / your sweetness is more cruel / than your hurt / ... Could Eros be kept? / he were prisoned long since / and sick with imprisonment /...Is it sweet / to possess utterly? / or is it bitter, / bitter as ash?

151 GUBAR 1984: 53-57.

152 DOOLITTLE 1982: 67, She is the island of artistic perfection where the lover of the ancient beauty (shipwrecked in the modern world) may find yet foothold and take breath and gain courage for new adventures and dream of yet unexplored continents and realms of future artistic achievement.

153 LOWELL 1955, 459-460, Taking us by and large, we're a queer lot / We women who write poetry. And when you think / How few of us there's been, it's queerer still. / ... There's Sapho, now I wonder what was Sapho. / ... she was like a burning birch-tree / ... A frozen blaze before it broke and fell. / Ah me, I wish I could have talked to Sapho, / Surprised her reticences by flinging mine / Into the wind. This tossing off of garments / Which cloud the soul is none too easy doing / ...To bare the loveliness of her words and tell / The reasons, as she possibly conceived them, / Of why they are so lovely...we two were sisters / Of a strange, isolated little family...But Sapho was dead / And I, and others, not yet peeped above the edge od possibility. So that's an end / To speculating over tea-time talks / ... I cannot write like you, I cannot think / In terms of Pagan or of Christian now. / ...And still my answer / Will never be any one of yours, I see. 
authors. However, in spite of this vigilance, all of them in similar or different ways associated Sappho and Lesbos with the concept of female homosexuality. ${ }^{154}$

This new paradigm produced a loud echo in the contemporary historical and philological studies about the poetess from Lesbos, which throughout the past century and a half almost unexceptionally addressed the subject of Sappho's sexuality or even made it the very focus of their interest. Having had the illusiveness of autobiographical reading of Sappho's poetry in mind, these studies turned to investigating the problematic relationship between the poetess and her lyric subject through the lens of two principal issues: Sappho's social role on the one hand and the performance style and context of her poems on the other hand. In addressing the first issue, modern philologists and historians subscribed to one of the four dominant explanatory models. They saw Sappho as either a schoolmistress, a chorus leader, a priestess or a banqueter.

The thesis about Sappho as a teacher of affluent young women was first outlined in the aforementioned $19^{\text {th }}$-century studies of Welcker and Müller and was further developed by the German classical scholar Ulrich von Willamowitz-Möllendorff, who ex nihilo constructed the theory of Sappho as the headmaster of a girls' school, where she presumably instructed young women in the arts of weaving and seduction in order to prepare them for normative marital life. Such circumstances allegedly resulted in the development of a close and intimate bond between the mentor and her pupils, which was later unjustly ascribed a homoerotic connotation. ${ }^{155}$ Despite having conducted a seemingly plausible analysis, WilamowitzMöllendorff fell victim to a bizarre anachronism by pulling the parallel between ancient Greek women's education and modern English and German single-sex schools. ${ }^{156}$ Additionally, his theory was essentially motivated by a desire to oppose the claims about Sappho's lesbianism, which had proliferated after the publication of The Songs of Bilitis. ${ }^{157}$ Nevertheless, his theory received wide support in the academic community, including in the Balkans. An example of this is the 1935 study of the Serbian philologist Miloš Đurić, who attempted to disengage Sappho's persona from all defamatory traditions that spoke about what he calls her, ,sexual psychopathy and perversion“", and instead represented her as a chaste and devoted wife and mother, as well as one among those Aeolian poets who brought archaic lyric poetry to its perfection in form and metric. ${ }^{158}$ Following Willamowitz-Mollendorff, Đurić ascribed Sappho the role of a schoolmistress who taught young women poetry, music, and the art of love in order to prepare them for marriage.

\footnotetext{
154 GUBAR 1984: 58-62.

155 WILAMOWITZ - MÖLLENDORFF 1913: 73-77.

156 RAYOR \& LARDINOIS 2014: 15.

157 HALLETT 1979: 451.

158 ĐURIĆ 1935: 8-11.
} 
Her erotology is equated with that of Socrates, which is interpreted as sublime, bodiless and platonic. Thus, according to Đurić, Sappho's erotic poetry would describe nothing more than a filial and platonic love for her pupils. ${ }^{159}$ Further proponents of the thesis about Sappho as schoolmistress divided themselves into two groups. The former entertained the notion that Sappho taught young women the art of composing and performing lyric poetry and hypothesized that Lesbos was home to a tradition of musical education of the daughters of noble families, which included sexual interaction between the mistress and her disciples similar to male pederastic bonds. ${ }^{160}$ The latter, including Hallett and Burnett, expanded this theory by suggesting that Sappho's epithalamia served the function of helping young unmarried girls to develop consciousness of their sexuality. ${ }^{161}$ However, both theories suffer from serious deficiencies. First of all, Sappho's poems neither mention the poetess in the capacity of a teacher nor do they state that she was accompanied only by younger women, which is essentially an idea first proposed by Ovid six centuries after the lyricist's death. ${ }^{162}$ Furthermore, there is no evidence confirming the existence of special schools for girls in ancient Greece and the only form of education a young Greek woman could get was singing and dancing in a chorus, in addition to gymnastic training in Sparta. ${ }^{163}$ What is more, Hallett's and Burnett's thesis about Sappho as sex educator uses the concept of male pederasty as an explanatory model, although it is well-known that in sex-segregated societies like the ancient Greek the socialization of boys and girls took on quite disparate paths. ${ }^{164}$ Most importantly, the methodology used by all successors of Willamowitz-Möllendorff is extremely problematic because it bases the selection and interpretation of historical records on a priori assumptions. ${ }^{165}$ Nonetheless, the theory about Sappho as a schoolmistress continues to live on with a strong support in contemporary historiography and philology.

After undergoing certain modifications and improvements, the model of Sappho as a schoolmistress evolved into the model of Sappho as a chorus organizer and leader, which some reputable philologists like Lardinois consider the most plausible. Its proponents refer to the choral character of several Sappho's songs, the existence of female choruses in archaic Greece, as well as the practice of choral poets to mentor and accompany choruses before and during their performances in order to purport that Sappho served as a teacher of choral singing. Some of them

159 ĐURIĆ 1935: 11-21.

160 BLUNDELL 1999: 84.

161 HALLETT 1979: 456-457; BURNETT 1983: 216-218.

162 PARKER 1993: 316-318.

163 RAYOR \& LARDINOIS 2014: 15.

164 PARKER 1993: 311.

165 PARKER 1993: 320-321. 
add that the poetess may have indulged in homosexual intercourse with her female trainees in this capacity. ${ }^{166}$ However, like the one formerly mentioned, this theory also overlooks the lack of proof for Sappho's role as a teacher or the exclusively maidenly membership of her immediate company and it proposes a universal explanatory model for Sappho's social role, to which it then adjusts the selection and analysis of relevant records. Moreover, nothing confirms the hypothesis about the existence of choral schools in archaic Greece, let alone of Panhellenic academies with the same purpose, directed by famous poets. ${ }^{167}$ Finally, many of Sappho's poems indicate a rather monodic and private performance context instead of public and choral one. ${ }^{168}$

By building upon the former two models, some researchers in the latter half of the $20^{\text {th }}$ century suggested that Sappho figured as the head of a female thiasos, dedicated to the worship of female deities like Aphrodite, the Graces and the Muses. The principal sources informing this theory are Sappho's religious hymns and later testimonies, which confirm that some of Sappho's poems were performed in temples during religious ceremonies. ${ }^{169}$ However, one has to bear in mind that other archaic poets like Alcaeus and Anacreon likewise wrote poetry dedicated to the gods and intended for performance on religious festivals, without having been attached an etiquette of priests or cult leaders. ${ }^{170}$

The most recent model dismisses the previous three and observes Sappho as a member of an informal circle of friends, who gathered on private aristocratic symposia, where they nurtured their family, political and erotic bonds. In order to support their views, the proponents of this thesis usually list three arguments. Firstly, there are several Sappho's poems, in which the poetess refers to her friends as heterai and philai. ${ }^{171}$ Second, a significant part of Sappho's opus is characterized by the frequency of symposium-related motives, such as wine jars, flower wreaths and perfumes. ${ }^{172}$ Thirdly, the imagery on four Athenian vases dated to the period between the $6^{\text {th }}$ century $\mathrm{BC}$ and the first half of the $5^{\text {th }}$ century $\mathrm{BC}$ connects Sappho with the context of a banquet. ${ }^{173}$ However, this theory should also be brought under scrutiny, since Sappho's poems were indeed performed on Greek symposia, but their participants were primarily men. Even if these banquets were organized to the accompaniment of weddings featuring female friends of

\footnotetext{
166 RAYOR \& LARDINOIS 2014: 15-16.

167 PARKER 1993: 333.

168 PARKER 1993: 331.

169 BLUNDELL 1999: 84.

170 PARKER 1993: 322.

171 PARKER 1993: 341.

172 PARKER 1993: 345.

173 RAYOR \& LARDINOIS 2014: 6.
} 
the bride, there is no sound proof that, in archaic Greece, there existed private or semi-private secular symposia reserved only for women. Notwithstanding the fact that some of Sappho's poems were performed in more private and less formal contexts, the heterogeneity of her opus renders us unable to associate her social role exclusively with the context of female banquets. ${ }^{174}$

When it comes to the analysis of the performance style and context of Sappho's poetry, contemporary historians and philologists again applied different approaches and delivered quite divergent conclusions. Some of them state that the complexity of this issue makes it impossible to bring any final judgments regarding Sappho's (homo)sexuality. For instance, Lardinois makes the question of Sappho's sexuality dependent upon the possibility of identifying the author with her lyric speaker, composing a typology of her songs according to their presumed performance context. In this sense, the religious hymns would have been performed by female choruses at public festivals dedicated to female deities, while the epithalamia could have been sung at both public and private marriage ceremonies by either female or mixed choruses, possibly even by soloists. In this connection Lardinois emphasizes that the homoerotic sentimentality of choral poems ought not to be interpreted as reflecting the nature of the bond between Sappho and her female acquaintances, but rather as expressing either a general praise of female beauty or the power of love. ${ }^{175}$ However, the situation is far more complex with satiric poems dedicated to specific persons, such as Andromeda or Gorgo, to whom the girls close to the lyric speaker professed their affection. Equally complicated are the poems addressing girls like Anactoria, Gongyla, Megara and Atthis, who abandon the speaker against her will. These poems contain clear homoromantic and homoerotic allusions, are dedicated to individual women in specific circumstances, with two of them explicitly identifying the speaker with the name Sappho. However, Lardinois is of the opinion that even this does not provide clear proof of poetess' homosexuality, since their performance style and context are unascertainable. In case they were performed publicly, the voice of the soloist or the chorus could have figured as a representative of the audience, of which it was expected not only to empathize, but also to identify with the lyric speaker, who would thus merely communicate the general consequences of fatal or unrequited love. Even if these poems were monodic and sung by Sappho herself in front of her friends, it still remains unclear if the female names they mention represent historical figures or a simple product of Sappho's imagination, claims Lardinois. ${ }^{176}$ Similarly, Yatromanolakis stresses the impossibility to reconstruct a single and universal performance context applicable to all Sappho's poems, since a single

174 RAYOR \& LARDINOIS 2014: 16.

175 RAYOR \& LARDINOIS 2014: 14.

176 RAYOR \& LARDINOIS 2014: 11-12. 
poem could be sung in different circumstances and in different ways. ${ }^{177}$ Most is of the opinion that Sappho initially wrote songs for a more private performance with the lyric speaker and her addressee representing actual persons known to the audience, but later shifted to writing songs for public play, wherefore the lyric persons became more general, even generic, which makes the homosexuality of their author impossible to ascertain. ${ }^{178}$ Parker takes contrary stance to Lardinois, Yatromanolakis and Most by claiming that the presumption about plurality of performance contexts needlessly complicates and mystifies the lyric speaker, reducing the issue of Sappho's homosexuality to the banal logical condition according to which the uncertainty about Sappho's homosexuality would prevail as long as there is no direct evidence that she copulated with other women. ${ }^{179}$ Blundell recognizes in Sappho's poetry plain homoerotic sentimentality, but confines herself from asserting final judgment by stating that Sappho was definitely lesbian on the level of poetic imagination. ${ }^{180}$ Equally cautious is Hallett, who admits that no Sappho's extant poem explicitly mentions the moment of homosexual coitus, but does not exclude the possibility that such poems once formed part of her opus, but were coincidentally or deliberately erased from history. ${ }^{181}$ Finally, Penrose calls attention to the most recent papyrological discovery, Fragment 58, in which the female speaker complains about her own aging, as demonstrated by her grey hair and weak knees, which could challenge the deeply-seated paradigm about the inappropriateness of autobiographical reading of Sappho's poetry and therefore enable the identification of the poetess with the lyric speaker. ${ }^{182}$

\section{Conclusion}

Despite the scarcity and unreliability of the information on Sappho's life and the availability of barely one tenth of her original opus, which significantly hampers the discussion about her professional, social and sexual identity, the extant corpus of her poetry represents a unique contribution to the European literature because of its ambivalent character. By virtue of innovative metrics, style and recontextualization of mythological motives, it reaches the artistic summit in adhering to conventional elements of the Greek lyric poetry, while simultaneously subverting that conventions by highlighting the feminine and homoerotic properties of its motives, diction and relationship between the lyric speaker and her addressees,

\footnotetext{
17 YATROMANOLAKIS 2009: 206-208.

178 MOST 1995: 32.

179 PARKER 1993: 333-334.

180 BLUNDELL 1999: 84.

181 HALLETT 1979: 453.

182 PENROSE 2014: 419.
} 
which inevitably caused confusion, scepticism and anxiety in the historically heteropatriarchal European culture. It is therefore possible to conceptualize that poetry as a "Trojan horse" and its historical reception as an attempt to tame and reclaim that horse. This attempt through millennia assumed the appearance of compulsory heterosexualization of Sappho's biography and poetry. While various ancient authors employed the discursive strategy of duplication in order to split Sappho into two historical figures, that of a glorious poetess and that of a notorious courtesan, Ovid established the discursive strategy of narrativization, which reinterpreted Sappho's homosexuality as a matter of her turbulent past and morally rehabilitated the poetess by inventing the story of her tragic love for Phaon. In modified forms, tuned to the actual cultural circumstances of particular historical periods, this strategy became an almost universal approach in the reception of Sappho until the end of the $19^{\text {th }}$ century. In this sense, early Christian texts, striving to emancipate themselves from the heritage of pagan antiquity, fervidly attacked and condemned Sappho's homosexual liaisons. In the context of Renaissance enthusiasm for imitation and emulation of ancient cultural models, the status of Sappho as an exquisite poet had to be reconciled with compromising traditions about her promiscuity and homoeroticism, which thus deliberately went unmentioned in literature. However, the late-Renaissance philology broached the uncomfortable subject of Sappho's sexuality, but all discussions about it assumed a judgmental and chastising homophobic tone, with Ovid still serving as the main point of reference. His authority became unquestionable in the early modern European literature and philology, which witnessed a wholehearted recourse to the discursive strategy of narrativization.

An important change in the reception of Sappho's sexuality came with Romanticism, when pride of place was handed over to the newly developed discursive strategy of condensation, which continued to rest on the $15^{\text {th }}$ Heroide, but onstructed Sappho as a tragic heterosexual heroine, who committed suicide in order to escape the anguishing contradiction between the spiritual sublimity and bodily superficiality. Ovid finally tarted losing his authority in the latter half of the $19^{\text {th }}$ century, when French and English Parnassian and decadent poets began to draw inspiration from presumed homoeroticism of Sappho's poetry, but they exploited it in a homophobic attempt to construct a morbid and decadent imaginarium of exotic lesbian promiscuity. In parallel with this, modern European philologists used the newly devised methods of critical analysis to either dismiss Sappho's homosexuality or ostracize it in a homophobic tone. Finally, during the fin de siècle, after almost two millennia of subjecting Sappho's poetry to the regime of compulsory heterosexuality, feminist and lesbian writers in their attempt to create women's literary tradition recognized in Sappho's surmised homoerotic poetic voice a potential for artistic and socio-political emancipation of women, reinventing the poetess as the first feminist and lesbian in the Western literary history. 
This cultural shift produced far-reaching epistemological consequences in modern academic approach to Sappho. Implementing the contemporary paradigms of literary criticism, according to which it is impossible to evaluate a piece of literature without considering the social and cultural context of its author, many researchers of Sappho's life and work found themselves trapped within a spellbound circle by trying to reconstruct the archaic Greek society based on the information in Sappho's poetry and then use these reconstructions as a point of departure in the analysis of her sexuality. What is very symptomatic in these attempts is the misogynistic inauguration of double-standards, according to which men like Alcaeus and Anacreon are seen simply as poets, whereas the poetry of a woman who created in the same literary tradition is subject to all kinds of explanatory models, which try to explain her artistic activity by constructing specific social roles she would have played and particular styles and contexts in which her poetry would have been performed. It can therefore conclusively be claimed that contemporary studies of Sappho, regardless of whether they confirm or dismiss her homosexuality, fall victim to the epistemological and methodological hypocrisy inasmuch as they turn gender and sexuality into criteria which predetermine the approach to her poetry, instead of evaluating it according to parameters of archaic Greek poetry, to which Sappho herself belonged and most probably identified with.

\section{Bibliography}

\section{Primary sources}

APULEIUS. 2017. Apologia. Florida. De Deo Socratis. Transl. Christopher P. Jones. Loeb Classical Library 534. Cambridge, MA: Harvard University Press.

ATHENAEUS. 2008. The Learned Banqueters, Volume IV: Books 8-10.420e. Transl. S. Douglas Olson. Loeb Classical Library 235. Cambridge, MA: Harvard University Press.

ATHENAEUS. 2011. The Learned Banqueters, Volume VII: Books 13.594b-14. Transl. S. Douglas Olson. Loeb Classical Library 345. Cambridge, MA: Harvard University Press.

BACHOFEN, Jakob Johann. 1897. Das Mutterrecht. Eine Untersuchung über die Gynaikokratie der alten Welt nach ihrer religiösen und rechtlichen Natur. Basel: Benno Schwabe.

BARTHÉMY, Jean-Jacques. 1826. Voyage de jeune Anacharsis en Grèce. Vol. 2. Paris: Dabo-Butschert.

BAUDELAIRE, Charles. 1857. Les Fleurs du Mal. Paris: Poulet-Malassis, De Broise.

BOCCACCIO, Giovanni. 2003. Famous Women. Transl. Virginia Brown. London - Cambridge - Massachussetts: The Renaissance Library, Harvard University Press.

CATULlUS. 1913. Catullus. Tibullus. Pervigillium Veneris. Transl. F. W. Cornish. Loeb Classical Library 6. Cambridge, MA: Harvard University Press.

DAUDET, Alphonse. 1884. Sapho: moeurs parisiennes. Paris: A. Lahure. 
DONNE, John. 1992. “Sappho to Philaenis”. In MUELLER 1992: 133-134.

DOOLITTLE, Hilda. 1968. Palimpsest. Eds. Harry T. Moore, Matthew J. Bruccoli. London - Amsterdam: Feffer \& Simmons.

DOOLITTLE, Hilda. 1982. Notes on Thought and Vision \& The Wise Sappho. San Francisco: City Lights Books.

DOOLITTLE, Hilda. 1983. Collected Poems 1912 - 1944. Ed. Louis L. Martz. New York: New Directions.

ERASMUS. 1725. All the Familiar Colloquies of Desiderius Erasmus, of Rotterdam. Transl. N. Bailey. London: J. Darby.

GRILLPARZER, Franz. 1947. „Sappho“. In Franz Grillparzers Werke, vol. 1, ed. Edwin Zellweker, 138-217. Vienna: Donau Verlag, 1947.

HORACE. 1926. Satires. Epistles. The Art of Poetry. Transl. H. Rushton Fairclough. Loeb Classical Library 194. Cambridge, MA: Harvard University Press.

HORACE. 2004. Odes and epodes. Transl. Nial Rudd. Loeb Classical Library 33. Cambridge, MA: Harvard University Press.

JUVENAL. 2004. Juvenal and Persius. Transl. Susanna Morton Braund. Loeb Classical Library 91. Cambridge, MA: Harvard University Press.

LABÉ, Louise. 2014. Love Sonnets and Elegies. Transl. Richard Sieburth. New York: NYRB.

LAMARTINE, Alphonse de. 1963. Oevures poétiques complètes. Ed. Marius-François Guyard. Paris: Bibliothéque de la Pléiade.

LE FÈVRE, Anne. 1716. Les Poesies d'Anacreonet de Sapho, Traduitesen Français, avec des remarques. Amsterdam: La Veuve de Paul Marret.

LEOPARDI, Giacomo. 2006. Canti: edizione critica. Ed. Franco Gavezzeni. Florence: L'Accademia della Crusca.

LOUŸS, Pierre. 1913. Les Chansons de Bilitis: traduites du Grec. Paris: Georges Crest et al.

LOWELL, Amy. 1955. The Complete Poetical Works. Boston: Houghton Mifflin.

LUCIAN. 1961. Dialogues of the Dead. Dialogues of the Sea-Gods. Dialogues of the Gods. Dialogues of the Courtesans. Transl. M. D. McLeod. Loeb Classical Library 431. Cambridge, MA: Harvard University Press.

LYLY, John. 1999. Campaspe and Sappho and Phao. Eds. David Bevington, G. K. Hunter. Manchester: Manchester University Press.

MARTIAL. 1993. Epigrams, Volume II: Books 6-10. Transl. D. R. Shackleton Bailey. Loeb Classical Library 95. Cambridge, MA: Harvard University Press.

MENANDER. 1997. Heros. Theophoroumene. Karchedonios. Kitharistes. Kolax. Koneiazomenai. Leukadia. Misoumenos. Perikeiromene. Perinthia. Transl. W. G. Arnott. Loeb Classical Library 459. Cambridge, MA: Harvard University Press.

MURE, William. 1854. A Critical History of the Language and Literature of Antient Greece. Vol. 4. London: Longman et al.

MÜLLER, Karl Otfried. 1875. Geschichte der griechischen Literatur. Eds. Eduard Müller, Emil Heitz. Stuttgart: Albert Heitz. 
OVID. 1914. Heroides. Amores. Transl. Grant Showerman. Loeb Clasical Library 41. Cambridge, MA: Harvard University Press.

OVID. 2015. Ars Amatoria, Book 3. Ed. Christopher M. Brunelle. New York - Oxford: Oxford University Press.

PIZAN, Christine de. 1992. The Book of the City of Ladies. Transl. Jeffrey Richards. New York: Persea Books.

PLINY. 1951. Natural History, Volume IV: Books 20 - 23. Transl. W. H. S. Jones. Loeb Classical Library 392. Cambridge, MA: Harvard University Press, 1951.

PROPERTIUS. 2004. The Complete Elegies of Sextus Propertius. Transl. Vincent Katz. Princeton: Princeton University Press.

ROBINSON, Mary. 1796. Sappho and Phaon in a Series of Legitimate Sonnets, with Thoughts on Political Subjects, and Anecdotes of the Grecian Poetess. London: S. Gosnell.

ROBINSON, Mary. 1799. The False Friend: A Domestic Story. London: T. N. Longman, O. Rees.

SAPPHO. 1982. In Greek Lyric I. Sappho and Alcaeus. Transl. David A. Campbell. Loeb Classical Library 142. Cambridge, MA: Harvard University Press.

SAPPHO. 2002. In If not, Winter. Fragments of Sappho. Transl. Anne Carson. New York: Vintage.

SCHLEGEL, Friedrich. 1979. „Uber die Grenzen des Schönen“. In Kritische Friedrich-Schlegel-Ausgabe: Studien des Klassischen Alertums, vol. 1, eds. Ernst Behler, Jean-Jacques Anstett, Hans Eichner, 38-45. Paderborn - München - Vienna: Verlag Ferdinand Schöningh.

SCUDÉRY, Madeleine de. 1656. Artamèneou le Grand Cyrus. Paris: Augustin Courbé.

SENECA. 1920. Epistles, Volume II: Epistles 66-92. Transl. Richard M. Gummere. Loeb Classical Library 76. Cambridge, MA: Harvard University Press.

SIDNEY, Sir Philip. 2003. The Countesse of Pembroke's Arcadia (1590). Ed. Risa Bear. Eugene: University of Oregon.

SUDA. 1998. In: Suda On Line. Transl. Elizabeth Vandiver, s. v. „Sappho“ (retrieved 8 February 2018).

SWINBURNE, Algernon Charles. 1866. Poems and Ballads. London: Savill \& Edwards.

TATIAN. 1982. Oratio ad Graecos and Fragments. Transl. Molly Whittaker. Oxford New York: Clarendon Press.

VERRI, Alessandro. 1793. Avventure di Saffo, poetessa di mitilene. Rome: Giuseppe Nave.

VIVIEN, Reneé. 1903. Sapho. Traduction nouvelle avec le texte grec. Paris: Alphonse Lemerre.

VIVIEN, Reneé. 1905. Un Femme m'apparut... Paris: Alphonse Lamerre.

WELCKER, Friedrich Gottlieb. 1816. Sappho von einem vorrherschenden Vorurteil Befreyt. Göttingen: Vandenhoek \& Ruprecht.

WILLAMOWITZ-MÖLENDORFF, Ulrich von. 1913. Sappho und Semonides: Untersuchungen der Griechischen Lyriker. Berlin: Weidmannsche Buchhandlung.

WOOLF, Virginia. 2011. “A Society”. In: Monday or Thursday: Eight Stories. New York: Dover Publications. 
WOOLF, Virginia. 2015. A Room of One's Own. Eds. David Bradshaw, Stuart N. Clarke. Chichester: Wiley-Blackwell.

Reference works

ACOSTA-HUGHES, Benjamin. 2004. "Alexandrian Posidippus: On Rereading GP Epigrams in Light of P.Mil.Vogl. VIII 309”. In Labored in Papyrus Laeaves: Perspectives on an Epigram Collection Attributed to Posidippus (P.Mil.Vogl. VIII 309), eds. Benjamin Acosta-Hughes, Elizabeth Kosmetatou, Manuel Baumbach, 35-48. Cambridge, MA: Harvard University Press.

ANDREADIS, Harriett. 2001. Sappfo in Early Modern England: Female Same-Sex Literary Erotics. 1550 - 1714. Chicago: Chicago University Press.

BEVINGTON, David, G. K. HUNTER. 1999. Campaspe and Sappho and Phao: John Lyly. Manchester: Manchester University Press.

BLUNDELL, Sue. 1999. Women in Ancient Greece. London: British Museum Press.

BREMER, Alida. 2004. "Gynotopia, Knjiga o gradužena' Christine de Pizan” [“Gynotopia, The Book of The City of Ladies' by Christine de Pizan”]. Kolo 4: 67-81.

BURNETT, Anne Pippin. 1983. Three Archaic Poets. Archilochus, Alcaeus, Sappho. Cambridge, MA: Harvard University Press.

ĐURIĆ, Miloš. 1935. Sapfa i etika njene partenofilije. Belgrade: Milan Sibinkić.

GREENE, Ellen. 1996. Re-reading Sappho: Reception and Transmission. Berkeley: University of California Press.

GUBAR, Susan. 1984. "Sapphistries”. Signs: Journal of Women in Culture and Society 10: 43-62.

HALLETT, Judith P. 1979. "Sappho and Her Social Context: Sense and Sensuality". Signs: Journal of Women in Culture and Society 4/3: 447-464.

MOST, Glenn W. 1995. "Reflecting Sappho". Bulletin of the Institute of Classical Studies 40: $15-38$.

MUELLER, Janel. 1992. “Lesbian Erotics: The Utopian Trope of Donne's Sappho to Philaenis"'. Journal of Homosexuality 23: 103-134.

PARKER, Holt N. 1993. "Sappho Schoolmistress". Transactions of the American Philological Association 123: 309-351.

PENROSE, Walter Jr. 2014. “Sappho's Shifting Fortunes from Antiquity to the Early Renaissance". Journal of Lesbian Studies 18/4: 415-436.

PUFF, Helmut. 2011. “Toward a Philology of the Premodern Lesbian”. In The Premodern Lesbian, edS. Noreen Griffney, Michelle M. Sauer, Diane Watt, 145-157. New York: Palgrave Macmillan.

RAYOR, Diane J., André LARDINOIS. 2014. Sappho: A New Edition of the Complete Works. Cambridge: Cambridge University Press.

REESER, Todd W. 2015. Setting Plato Straight: Translating Ancient Sexuality in the Renaissance. Chicago: University of Chicago Press. 
RICH, Adrienne. 1980. "Compulsory Heterosexuality and Lesbian Existence”. Signs 4: 631-660. ROTSTEIN, Andrea. 2016. Literary History in The Parian Marble. Washington D. C.: Center for Hellenic Studies.

SCHACHTER, Marc. D. 2015. "Lesbian Philology in Early Print Commentaries on Juvenal and Martial“. In Ancient Rome and the Construction of Modern Homosexual Identities, ed. Jennifer Ingleheart, 39-55. Oxford - New York: Oxford University Press.

SCHLESIER, Renate. 2013. „Sappho“. In Historische Gestalten der Antike. Rezeption in Literatur, Kunst und Musik [Der Neue Pauly. Supplemente. Vol. 8], eds. Peter von Möllendorff, Annette Simonis, Linda Simonis. Stuttgart, Weimar: Metzler.

TY, Eleanor. 1997. Empowering the Feminine: The Narratives of Mary Robinson, Jane West and Amelia Opie, 1796 - 1812. Toronto: University of Toronto Press.

WINKLER, J. J. 2002. "Double Consciousness in Sappho's Lyrics.” In Sexuality and Gender in the Classical World, ed. Laura K. McClure, 38-71. Oxford: Blackwell. WILLIAMS, Margaret. 1995. Sappho's Immortal Daughters. Cambridge, MA: Harvard University Press.

WITTIG, Monique. 2010. 'Hetero'um i drugi eseji ['Heterosexual'mind and other essays]. Transl. Katmerka Kurtović. Zagreb: Lesbian group Kontra.

WITTIG, Monique, Sande ZEIG. 1979. Lesbian Peoples: Material for a Dictionary. New York: Avon.

YATROMANOLAKIS, Dimitrios. 2009. "Alcaeus and Sappho". In The Cambridge Companion to Greek Lyric, ed. Felix Budelmann, 204-226. Cambridge: Cambridge University Press.

\section{Trojanski konj? Sapfina poezija kao bojno polje između prisilne heteroseksualnosti i lezbijske emancipacije}

Starogrčku se pjesnikinju Sapfu naširoko shvaća kao najstariju poznatu lezbijku i feministkinju u povijesti zapadnjačke književnosti. Međutim, ova uobičajena interpretacija tek je jedna u tisućljetnom nizu reinvencija njezine ličnosti, čija se heteroseksualnost prije fin de sièclea shvaćala kao bespogovorna istina. U ovom se radu nastoji objasniti kako se recepcija Sapfine poezije tijekom povijesti nužno suočavala s pitanjem pjesnikinjine seksualnosti, kojoj je pristupala na znatno različite načine. Najprije se koriste teorijski koncepti trojanskoga konja i prisilne heteroseksualnosti feminističkih kritičarka Monique Wittig i Adrienne Rich kako bi se ukazalo na činjenicu da je (homo)erotska sentimentalnost Sapfinih veličanstvenih pjesama izazvala moralni kompleks u heteropatrijarhalnom društvu, koje je, shodno tomu, tu poeziju pokušavalo pripitomiti i prisvojiti. Rad se potom okreće dijakronijskoj analizi raznolikih diskurzivnih strategija heteroseksualizacije unutar zapadnjačkih književnih i filoloških diskursa od antike do moderne, suprotstavljajući ih suvremenom diskursu homoseksualizacije, kako 
bi se dokazalo da je Sapfinu historijsku recepciju moguće poimati kao ideološku borbu između tradicionalnog epistemološkog režima prisilne heteroseksualnosti i suvremenog političkog pokreta za lezbijsku emancipaciju oko davanja značenja njezinoj poeziji. Na samome se kraju rada pozornost usmjerava na najrecentnija filološka i historiografska istraživanja koja, u nastojanju izbjegavanja te ideološke borbe, nesvjesno upadaju u tisućljetnu mizoginiju nauštrb najveće pjesnikinje europske antike.

Keywords: Sappho, ancient Greek poetry, LGBT history, feminist history, Monique Wittig, Adrienne Rich.

Ključne riječi: Sapfa, starogrčka poezija, LGBT povijest, feministička povijest, Monique Wittig, Adrienne Rich.

Matia Anna Pleše

Filozofski fakultet Sveučilišta u Zagrebu Ivana Lučića 3, HR-10000 Zagreb matija.anna.plese@gmail.com 


\section{FILOZOFSKI FAKULTET SVEUČILIŠTA U ZAGREBU \\ ZAVOD ZA HRVATSKU POVIJEST \\ INSTITUTE OF CROATIAN HISTORY \\ INSTITUT FÜR KROATISCHE GESCHICHTE}

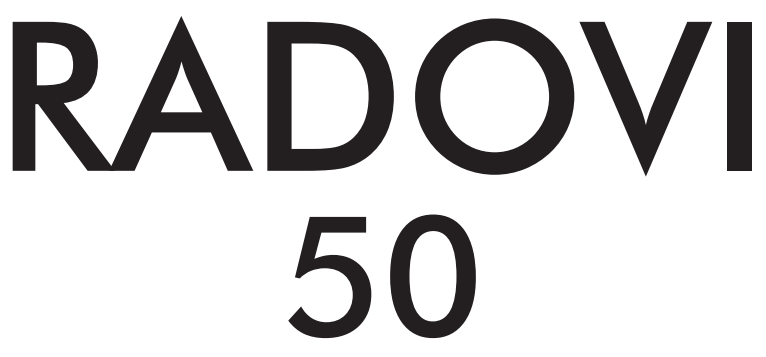

BROJ 2

ZAVOD ZA HRVATSKU POVIJEST

FILOZOFSKOGA FAKULTETA SVEUČILIŠTA U ZAGREBU

\section{FF press}

ZAGREB 2018. 


\title{
RADOVI ZAVODA ZA HRVATSKU POVIJEST FILOZOFSKOGA FAKULTETA SVEUČILIŠTA U ZAGREBU
}

\author{
Knjiga 50, broj 2
}

\author{
Izdavač / Publisher \\ Zavod za hrvatsku povijest \\ Filozofskoga fakulteta Sveučilišta u Zagrebu \\ FF-press \\ Za izdavača / For Publisher \\ Vesna Vlahović Štetić \\ Glavni urednik / Editor-in-Chief \\ Hrvoje Gračanin \\ Izvršni urednik / Executive Editor \\ Nikola Anušić \\ Uredništvo / Editorial Board
}

Bruna Kuntić-Makvić (stara povijest/ancient history), Zrinka Nikolić Jakus (srednji vijek/

medieval history), Hrvoje Petrić (rani novi vijek/early modern history), Željko Holjevac (moderna povijest/modern history), Tvrtko Jakovina (suvremena povijest/contemporary history),

Silvija Pisk (mikrohistorija i zavičajna povijest/microhistory and local history),

Zrinka Blažević (teorija i metodologija povijesti/theory and methodology of history)

Međunarodno uredničko vijeće / International Editorial Council

Denis Alimov (Sankt Peterburg), Živko Andrijašević (Nikšić), Csaba Békés (Budapest), Rajko Bratož (Ljubljana), Snježana Buzov (Columbus, Ohio), Svetlozar Eldarov (Sofija), Toni Filiposki

(Skopje), Aleksandar Fotić (Beograd), Vladan Gavrilović (Novi Sad), Alojz Ivanišević (Wien),

Egidio Ivetić (Padova), Husnija Kamberović (Sarajevo), Karl Kaser (Graz),

Irina Ognyanova (Sofija), Géza Pálffy (Budapest), Ioan-Aurel Pop (Cluj),

Nade Proeva (Skopje), Alexios Savvides (Kalamata), Vlada Stanković (Beograd),

Ludwig Steindorff (Kiel), Peter Štih (Ljubljana)

Izvršni urednik za tuzemnu i inozemnu razmjenu /

Executive Editor for Publications Exchange

Martin Previšić

Tajnik uredništva / Editorial Board Assistant

Dejan Zadro

Adresa uredništva/Editorial Board address

Zavod za hrvatsku povijest, Filozofski fakultet Zagreb, Ivana Lučića 3, HR-10 000, Zagreb

Tel. ++385 (0)1 6120 150, 6120 158, faks ++385 (0)1 6156879

Časopis izlazi jedanput godišnje / The Journal is published once a year

Časopis je u digitalnom obliku dostupan na / The Journal in digital form is accessible at

Portal znanstvenih časopisa Republike Hrvatske „Hrčak“ http://hrcak.srce.hr/radovi-zhp

Financijska potpora za tisak časopisa / The Journal is published with the support by Ministarstvo znanosti, obrazovanja i športa Republike Hrvatske

Časopis je indeksiran u sljedećim bazama / The Journal is indexed in the following databases: Directory of Open Access Journals, EBSCO, SCOPUS, ERIH PLUS, Emerging Sources Citation Index - Web of Science 


\title{
Naslovna stranica / Title page by
}

Iva Mandić

\section{Grafičko oblikovanje i računalni slog / Graphic design and layout Marko Maraković}

\author{
Lektura / Language editors \\ Samanta Paronić (hrvatski / Croatian) \\ Dražen Nemet (engleski / English)
}

Tisak / Printed by

Tiskara Zelina, Sv. Ivan Zelina

Naklada / Issued

200 primjeraka / 200 copies

Časopis je u digitalnom obliku dostupan na Portalu znanstvenih časopisa Republike Hrvatske „Hrčak“ http://hrcak.srce.hr/radovi-zhp

The Journal is accessible in digital form at the Hrcak - Portal of scientific journals of Croatia http://hrcak.srce.hr/radovi-zhp 